\title{
NATIONAL BUREAU OF STANDARDS REPORT
}

10402

\section{A FEASIBILITY STUDY OF TOTAL ENERGY SYSTEMS FOR BREAKTHROUGH HOUSING SITES}

\author{
Report to \\ Office of the Assistant Secretary \\ for Research and Technology \\ Department of Housing and Urban Development \\ Washington, D. C. 20410
}

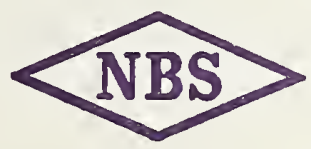

U.S. DEPARTMENT OF COMMERCE

NATIONAL BUREAU OF STANDARDS 
The National Rurcau of Standards' was established by an act of Congress March 3, 1901. The Bureau's overall goal is to strengthen and advance the Nation's science and fechnology and facilitale their effective application for puhlic benefit. To this end, the Bureatu conducts researeh and provides: (1) a hasis for the Nation's physical measurement system, (2) scientific and technological services for industry and government, (3) a technical bassis for equity in trade, and (4) technical services to promote public safety. The Bureau consists of the Institute for Basic Standards, the Institute for Materials Research, the Institute for Applied Technology, the Center for Computer Seiences and Technology, and the Office for Information Programs.

THE INSTITUTE FOR BASIC STANDARDS provides the central basis within the United States of a complete and consistent system of physical measurement; coordinates that system with measurement systems of other nations; and furnishes essential services leading to accurate and uniform physical measurements throughout the Nation's seientific community, industry, and commerce. The Institute consists of a Center for Radiation Research, an Office of Measurement Services and the following divisions:

Applied Mathematies-Electricity-Heat-Mechanies-Optical Physies-Linac Radiation"-Nuclear Radiation"-Applied Radiation"-Quantum Electronies" Electromagnetics ${ }^{3}$ - Time and Frequency ${ }^{3}$ - Laboratory Astrophysies ${ }^{3}-$ Cryogenics".

THE INSTITUTE FOR MATERIALS RESEARCH conducts materials research leading to improved methods of measurement, standards, and data on the properties of well-characterized materials needed by industry, commerce, educational institutions, and Government; provides advisory and researeh services to other Government agencies; and develops, produces, and distributes standard reference materials. The Institute consists of the Office of Standard Reference Materials and the following divisions:

Analytical Chemistry-Polymers-Metallurgy-Inorganic Materials-Reactor Radiation-Physical Chemistry.

THE INSTITUTE FOR APPLIED TECHNOLOGY provides technical services to promote the use of available technology and to facilitate technological innovation in industry and Government; cooperates with public and private organizations leading to the development of teehnological standards (including mandatory safety standards), codes and methods of test; and provides technical advice and services to Government ageneies upon request. The Institute also monitors NBS enginecring standards aetivities and provides liaison between NBS and national and international engineering standards bodies. The Institute consists of a Center for Building Technology and the following divisions and offices:

Engineering Standards Serviees-Weights and Measures-Invention and Innovation-Product Evaluation Teehnology-Electronic Technology-Technical Analysis-Measurement Engincering-Fire Technology-Housing Technology ${ }^{4}$ -Federal Building Technology ${ }^{4}$ - Building Standards and Codes Services ${ }^{4}$ Building Environment ${ }^{4}$-Struetures, Materials and Life Safety ${ }^{4}$ - Technical Evaluation and Application ${ }^{4}$.

THE CENTER FOR COMPUTER SCIENCES AND TECHNOLOGY conducts research and provides technical services designed to aid Government agencies in improving cost effectiveness in the conduct of their programs through the sclection, acquisition, and effective utilization of automatic data processing equipment; and serves as the principal focus within the executive branch for the development of Federal standards for automatic data processing equipment, techniques, and computer languages. The Center consists of the following offices and divisions:

Information Processing Standards-Computer Information-Computer Services - Systems Development-Information Processing Technology.

THE OFFICE FOR INFORMATION PROGRAMS promotes optimum dissemination and accessibility of seientific information generated within NBS and other agencies of the Federal Government; promotes the development of the National Standard Reference Data System and a system of information analysis centers dealing with the broader aspects of the National Measurement System; provides appropriate services to ensure that the NBS staff has optimum accessibility to the scientific information of the world, and directs the public information activities of the Bureau. The Office consists of the following organizational units:

Office of Standard Reference Data-Office of Technical Information and Publications-Library-Office of International Relations.

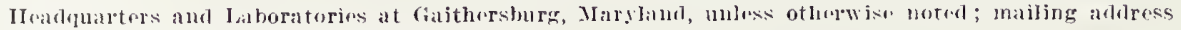
Washington, I) C. 202:34

Jart of the cinter for Radiation Resiarch.

Located at Boulder, Colorado 80302.

A Part of the Center for Building 'l'echnology.
} 


\title{
NATIONAL BUREAU OF STANDARDS REPORT
}

NBS PROJECT

4213402

August 12, 1971

NBS REPORT

10402

\section{A FEASIBILITY STUDY OF TOTAL ENERGY SYSTEMS FOR BREAKTHROUGH HOUSING SITES}

\author{
by \\ P. R. Achenbach \\ J. B. Coble \\ B. C. Cadoff \\ T. Kusuda \\ Sensory Environment Branch \\ Building Research Division \\ Institute for Applied Technology \\ National Bureau of Standards \\ Report to \\ Office of the Assistant Secretary \\ for Research and Technology \\ Department of Housing and Urban Development \\ Washington, D. C. 20410
}

IMPORTANT NOTICE

NATIONAL BUREAU OF STAN for use within the Government. Be and review. For this reason, the $p$ whole or in part, is not authorize Bureau of Standards, Washington, the Report has been specitically pri
Approved for public release by the director of the National Institute of Standards and Technology (NIST) on October 9, 2015 accounting documents intended bjected to additional evaluation sting of this Report, either in Jffice of the Director, National he Government agency for which ies for its own use.

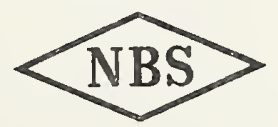

U.S. DEPARTMENT OF COMMERCE

NATIONAL BUREAU OF STANDARDS 

A FEASIBILITY STUDY OF TOTAL ENERGY SYSTEMS FOR

BREAKTHROUGH HOUSING SITES

by

P. R. Achenbach, J. B. Coble, Barry Cadoff, T. Kusuda

ABSTRACT

A feasibility study of the application of total energy systems to the prototype BREAKTHROUGH housing sites of the Department of Housing and Urban Technology was undertaken by the Building Research Division of the National Bureau of Standards under memorandum of agreement, IAA-H30-70. Total energy systems were investigated as alternative utility systems for future application where low reserves in conventional energy sources might exist or where the extension of conventional utility systems might be impractical.

A11 eleven sites in the BREAKTHROUGH program were originally considered, but five were eliminated in an early screening because of the small number and low density of the proposed dwelling units on these sites. The six remaining sites at Jersey City, Memphis, Macon, St. Louis, Sacramento, and Indianapolis were studied in relation to fourteen different parameters considered to have a bearing on their suitability for a prototype total energy system. These parameters included factors of technical, administrative, and economic significance.

The feasibility study resulted in recommendations of the Jersey City site as a first choice for the installation of a diesel-powered total energy system and the Memphis site as an alternate first choice using natural gas as the fuel. The Macon site was recommended as a good choice for a split system using a typical total energy system for the more denselyoccupied part of the site and all-electric mechanical equipment, served by the total energy system, in the less densely-occupied areas. The $\mathrm{St}$. Louis site was recommended as a third choice because the developments of the two parcels of ground comprising that site were similar. It thus offered an opportunity for a direct experimental comparison of the reliability, ecological, economic, and aesthetic aspects of a total energy system on one parcel of gound with a conventional system on the other parcel of ground a few blocks away. 

A FEASIBILITY STUDY OF TOTAL, ENERGY SYSTEMS FOR BRI:AKTHROUGII IOUSING SITES

Table of contents

ABSTRACT

$\underline{\text { Page }}$

1. Introduction 1

2. Tota1 Energy System Application 2

2.1 System Loads . . 2

2.2 Equipment Combinations 3

3. Ranking Parameters 3

4. Analysis of Ranking Parameters 4

4.1 Housing System Data $\quad 4$

4.2 Climatic Factors 6

4.3 Analysis of Energy Use $\quad 8$

4.4 Energy Cost Data 23

4.5 First Cost and Operating Cost 31

4.6 Adaptability of Housing Systems to Total Energy 37

4.7 Community Development 37

4.8 Environmenta1 Factors 39

4.9 Energy Resources $\quad 40$

4.10 Site Planners and Site Developers Attitudes 41

4.11 Time Schedule $\quad 42$

4.12 Application of Ranking Parameters to Six Sites 42

5. Interface with Solid Waste Systems 45

6. Recommendations 46

$\begin{array}{lr}\text { 7. References } & 48\end{array}$ 

Title

Table 1 Number of Dwelling Units to be built on Six Prototype BREAKTHROUGH Sites by Various Housing System Producers

Table 2 Site Size and Dwelling Unit Density on Six BREAKTHROUGH Sites

Table 3 Climatic Data for Six BREAKTHROUGH Sites

Table 4 Degree Days

Table 5 Monthly Maximum and Minimum Temperature

Table 6 Electrical and Domestic Hot Water Demand and Usage per Dwelling Unit

Table 7 Annual Energy Usage Profile for Jersey City

Table 8 Calculated Annual Energy Requirements for Various Systems

Table 9 Annual Energy Cost for Various Energy Systems

Table 10 Unit Energy Costs

Table 11 Ratio of Energy Costs per Unit of Heating Value of Fuels

Table 12 Comparative Equipment Sizes and Systems Costs for Total Energy and Conventional Systems

Table 13 Comparison of First Cost Increase and Annual Fuel Cost Reduction for Total Energy and Conventional Systems

Table 14 Rank Ordering of Six BREAKTHROUGH I Sites for Experimental Total Energy Systems 



\section{List of Figures}

Figure 1 Energy System Cycles

Figure 2 Annual Energy Cost for Various Energy Systems at Jersey City BREAKTHROUGH Site

Figure 3 Cost Comparisons of Total Energy Systems Employing A11 Absorption Cooling, A11 Compressor Cooling and Mixed Absorption Compressor Cooling

Figure 4 Natural Gas Rates

Figure 5 Electric Rates 

A FEASIBILITY STUDY OF TOTAL ENERGY SYSTEMS FOR

BREAKTHROUGH HOUSING SITES

\section{INTRODUCTION}

Concurrent with the national effort to accelerate the construction of housing in the United States, much attention has been drawn to the continued availability of some forms of energy used in housing and to the effects of energy use on environmental quality. Low reserves in electrical generating capacity exist in many highly populated areas of the country because of the rapid expansion of mechanization and because of the litigation over the potential air and water pollution caused by new large generating stations. Also very significant are the current restrictions in some areas to the addition of large increments of load to the natural gas distribution system.

These and other factors have caused the Department of Housing and Urban Development to explore pilot programs on the application of energy systems to BREAKTHROUGH housing that would give careful attention to the efficient use of energy, control of the noise generated, and limitation of air and water pollution as well as the more conventional concerns of economy and service life of equipment. In this context the Department of Housing and Urban Development has requested the National Bureau of Standards to examine the feasibility of experimentally applying total energy systems to one or more of the prototype BREAKTHROUGH housing sites to develop reliable data on these systems as primary or complementary utility options.

This feasibility study has included an analysis of the energy requirements for all uses at the sites; a study of comparative availability and cost of various fuels; an investigation of the various kinds of mechanical equipment being manufactured; an estimate of the cost of owning and operating total energy systems; a study of the extent of which laboratory studies of mechanical components is needed; and the compatibility of the total energy concept with the various housing systems, site plans, and development schedules at the several sites. These studies form the basis for the recommendations detailed later in this report for the application of innovative energy systems to some of the prototype BREAKTHROUGH housing sites. All information regarding loads, housing system types and numbers, natural gas and fuel oil costs, etc. is current as of August 1970. 


\section{TOTAL ENERGY SYSTEM APPLICATION}

The generally accepted industry definition of a total energy system for commercial or residential applications is a system that uses a prime mover for on-site generation of electricity and provides other equipment for useful application of the waste heat from the prime mover. A somewhat more generalized definition is used for industrial applications.

Under favorable conditions the electric energy requirements and the possible uses of the waste heat of a given application are so proportioned that the total amount of energy utilized by the total energy

system is significantly less than would occur if electric energy was taken from a central utility system and the other energy requirements were supplied by fuel-burning equipment at the site. To the extent that this favorable balance of loads occurs, there is good potential for lowering fuel costs and, in some cases, overall annual cost for energy by utilizing a total energy system.

Corollary benefits sometimes claimed for total energy systems are: greater reliability in electric service, conservation of energy resources, and overall reduction in the discharge of heat and combustion gases into the environment.

\subsection{System Loads}

The principal loads on a total energy system in a residential application are: electricity for lighting, motors, and appliances; space heating; space cooling; and domestic hot water heating. If there is community development associated with the site there will be other types of loads on the system that are characteristic of the particular facilities. There are daily, weekly, and seasonal cycles to the four principal components of the load in a residential application of a total energy system. The miscellaneous electrical load is likely to reach a maximum in the evening and the average usage from midnight to daylight may be no more than a third to a half of the daytime average. The domestic hot water demand will typically have maximum values in the late forenoon and in the evening. The demand for hot water is also low after midnight. The energy required for space heating is high from mid-evening to sunup and lower during the day and, of course, is seasonal. The energy required for space cooling is highest from noon to mid-evening and is complementary to the space heating requirements on a seasonal basis. There is usually one spring month and one fall month when little heating or cooling is required. 
It is obvious from the above summary that a good integration of the electrical demands and the utilization of the accompanying waste heat is not always possible. Some capability for auxiliary heating and for dumping unneeded heat is usually provided in a total energy system. Certain types of loads from commercial or community facilities help to improve the overall balance between electrical demand and the demands for waste heat.

\subsection{Equipment Combinations}

Total energy systems can be designed to utilize a variety of fuels; namely, natural or liquefied gas, fuel oil or diesel fuel, gas and oil in combination, coal, or nuclear energy. A high percentage of the systems that have been installed in the last decade have used natural gas, diesel fuel, or gas and oil in combination. Coal is not being recommended as an energy source for an experimental installation because of the problems of fuel and ash handling, and because of the limitations on fue 1 choice presented by air pollution regulations. Nuclear energy was eliminated from consideration for small sites because of the special technical problems associated with its use.

A wide variety of mechanical equipment is available for combination into total energy systems. Reciprocating engines or turbines using natural gas, liquefied petroleum gas, or diesel fuel can be used as the prime movers for driving an electric generator or an air conditioning compressor, which may be either of the reciprocating or centrifugal type. Steam turbines can be used as the prime movers for the generator or the air conditioning compressor, using a boiler to generate steam at an appropriate pressure. Absorption water chillers can be used to provide air conditioning. Space heating can be accomplished by electric resistance heating or by circulating steam or hot water. Space heating and cooling can be provided by heat pumps. Domestic water heating can be done by utilizing waste heat and a heat exchanger, or by using gas, oil, or electric energy directly as the heating source. Not all of these equipment choices lend themselves to an efficient utilization of waste heat or to attaining an optimum relation between electric energy requirements and waste heat requirements in a total energy system when considering the daily and seasonal load variations. However, a number of combinations should be considered for any given installation.

\section{RANKING PARAMETERS}

Approximately fourteen different farameters were determined to have some bearing on the relative suitability of the several BREAKTHROUGH sites for an experimental total energy system. These parameters can be separated into three groups having primarily technical, administrative, or economic significance. 
The parameters of a technical nature were: the number of dwelling units and their density and arrangement on the site; the sumer and winter degree days and the winter design temperature at the site; and the method of construction and assembly of the housing systems as related to the ease in bringing the utilities into the houses. The administrative considerations were: the number of different housing systems to be built on the site; the current and anticipated level of electric capacity reserves applicable to the site; the amount and kind of community development to be provided on the site; the time schedule for beginning of construction; and the knowledge and interest of the site planner and site developer in a pilot installation of a total energy system. The financial parameters were: the relative cost of purchased electrical, gas and oil energy at the site; the first cost difference between the total energy system and the conventional system which it might replace; and the cost of maintenance and repair.

Information was collected on the relative magnitude or importance of al1 of these parameters for the six BREAKTHROUGH sites that appeared to be better suited to total energy systems; namely, Jersey City, Memphis, St. Louis, Macon, Sacramento, and Indianapolis. The other five sites were eliminated in an earlier selection based mainly on the number and density of dwelling units on the sites. A ranking of the six sites, one against the other, is provided later in this report for all of the significant parameters. Not all of the parameters would normally be given equal weight in the decision-making process. This aspect will be discussed in connection with the specific recommendations for choice of sites.

\section{ANALYSIS OF RANKING PARAMETERS}

All the relevant information on the several ranking parameters that was available at this stage of the planning of housing on the prototype BREAKTHROUGH sites was assembled as a background for this feasibility study. This information is presented and discussed under several topical headings, and summarized in a single table at the end of this section.

\subsection{Housing System Data}

The housing systems that will be placed on each of the six BREAKTHROUGH sites that are being considered for total energy systems are summarized in Table 1. The number of each type of system to be built on each site is also shown in Table 1, based on data furnished by the site planners under date of August 12. A few of the numbers are still subject to change, as indicated in the table. The six sites chosen for detailed consideration as experimental sites for total energy systems were those with the highest number of dwelling units, since a total energy system is not usually considered to be economical for less than about 200 dwelling units. 
Table 1. Number of Dwelling Units to be Built on Six Prototype BREAKTHROUGH Sites by Various Housing System Producers.

Housing System Producer

Alcoa Constr. Systems, Inc.

Henry C. Beck Co.

Boise-Cascade Housing Development

CAMCI/MCI (Module Communities,Inc.)

Christiana Western Structures

Descon-Concordia Systems, Ltd. FCE-Dillon (Forest City)

General Electric Company

Hercules Incorporated

Home Building Corporation

Material Systems, Inc.

National Homes, Inc.

Pantek Corp. (Ball Brothers)

Pemtom Inc.

Republic Steel

Rouse-Wates, Inc.

Scholz Homes, Inc.

Shelley Systems, Inc.

Stirling-Homex Corp.

Townland Corp. (Keene)

TRW Systems Group

Totals

$\begin{array}{ll}\text { Indian- Jersey } \\ \text { apolis } & \text { City }\end{array}$

Site

apolis City Macon Memphis mento Loui

$50^{a}$

$50^{\mathrm{a}}$

20

14

$50^{\circ}$

20

$50^{\mathrm{a}}$

175

126

51

77

71

110

58

75

10

50

40

45

20

40

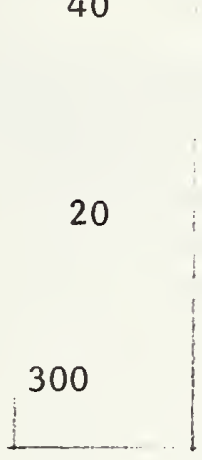

225

150

92

200

145

225

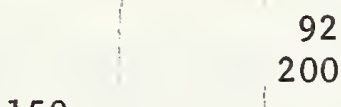

\begin{tabular}{|c|c|c|c|}
10 & $4^{\mathrm{b}}$ & 20 \\
500 & 323 & 476 & 400
\end{tabular} 
Table 2 shows the size of the six sites and the percentage of the dwelling units that will be built in high-rise buildings and as single-family detached homes. Since a total energy system delivers energy-related services from a central source, the cost of distribution is inversely related to the size of the site and the density of the dwelling units on the site. Of the six sites chosen for this comparison, only Indianapolis has no high-rise structure. On the other five sites, from 22 to 61 percent of the dwelling units are in high-rise buildings. From a density standpoint, there is a significant difference between Jersey City, Memphis, and St. Louis as one group, and Macon, Sacramento, and Indianapolis as a second group.

\subsection{C1imatic Factors}

The climatic factors that have a direct bearing on the economy and efficiency of a total energy system for a residential development are the summer and winter outdoor design temperatures and the degree-days of heating and cooling for each site. Since the economy of a total energy system is dependent on making use of the waste heat from the enginegenerator equipment used for electric power production, it is important that there be a reasonably steady demand for the waste heat throughout the year. In a typical residential application, the heating of domestic hot water and space heating requirements may utilize only one-third to one-half of the waste heat available during the four or five warmest months of the year. Thus a total energy system would not usually be economical in a residential application unless summer air conditioning is provided, or unless there is another summer use for waste heat of comparable magnitude in some type of community development.

The significant weather data for the six sites under consideration are shown in Table 3. The winter outdoor design temperature and the total winter degree-days are important to the first cost of the total energy system because in cooler climates these factors may determine the size of the boiler required to supplement the waste heat from the engine generator and the amount of time it will be operated in the winter time. In warmer climates the number of hours during the summer when the wet bulb temperature is at $67^{\circ} \mathrm{F}$ or above is a good indicator of the amount of time that air conditioning will be required in most areas of the United States. However, this is not an adequate indicator for air conditioning requirements in drier climates such as Sacramento. If an absorption system is used for air conditioning, the size of boiler needed for supplementing the waste heat from the engine-generator set is more 1ikely to be determined by the summer design conditions and the number of hours with an outdoor wet bulb of $67^{\circ} \mathrm{F}$ or higher. In Macon, Memphis, and Sacramento, the cooling load during the hottest months is expected to exceed the heating load during the coldest months. Thus it is important that efficient use be made of the energy required for air conditioning at these three sites. 
Table 2. Site Size and Dwelling Unit Density on Six BREAKTHROUGH Sites.

\begin{tabular}{|c|c|c|c|c|c|c|c|}
\hline \multirow{3}{*}{ Site } & \multirow{3}{*}{$\begin{array}{l}\text { Area, } \\
\text { acres }\end{array}$} & \multicolumn{6}{|c|}{ Dwelling Units } \\
\hline & & \multicolumn{2}{|l|}{ Total } & \multicolumn{4}{|c|}{ Percentage of Total } \\
\hline & & Units & MFHR & MFMR & MFLR & $\underline{\text { SFA }}$ & SFD \\
\hline Jersey City & 6.35 & 500 & 43 & 33 & 16 & 8 & - \\
\hline Macon & 50.0 & 321 & 22 & - & 17 & 58 & 3 \\
\hline Memphis & 14.2 & 476 & 61 & -- & 22 & 17 & - \\
\hline Indianapolis & $40-42$ & 308 & -- & 12 & 27 & 24 & 37 \\
\hline St. Louis & 10.58 & 446 & 37 & -- & 42 & 21 & -- \\
\hline Sacramento & 32 & 400 & 28 & - & 22 & 46 & 4 \\
\hline
\end{tabular}

Table 3. Climatic Data for Six BREAKTHROUGH Sites

\begin{tabular}{|c|c|c|c|c|c|}
\hline \multirow[t]{3}{*}{ Site } & \multicolumn{2}{|c|}{ Winter } & \multicolumn{3}{|c|}{ Summer } \\
\hline & \multirow[t]{2}{*}{$\begin{array}{l}\text { Degree- } \\
\text { days }\end{array}$} & \multirow[t]{2}{*}{$\begin{array}{l}\text { Outdoor } \\
\text { Design } \\
\text { temp, }{ }^{\circ} \mathrm{F} \\
\end{array}$} & \multirow[t]{2}{*}{$\begin{array}{l}\text { Hours at } \\
67^{\circ} \mathrm{F} \text { WB } \\
\text { or above }\end{array}$} & \multicolumn{2}{|c|}{$\begin{array}{l}\text { Outdoor } \\
\text { Design } \\
\text { temp, }{ }^{\circ} \mathrm{F}\end{array}$} \\
\hline & & & & $\underline{\mathrm{DB}}$ & WB \\
\hline Jersey City & 5067 & 15 & 1290 & 89 & 76 \\
\hline Macon & 2130 & 27 & 3069 & 96 & 79 \\
\hline Memphis & 3233 & 21 & 2631 & 96 & 79 \\
\hline Ind ianapolis & 5699 & 4 & 1462 & 91 & 77 \\
\hline St. Louis & 4900 & 11 & 1866 & 94 & 78 \\
\hline Sacramento & 2773 & 32 & 351 & 97 & 70 \\
\hline
\end{tabular}




\subsection{Analysis of Energy Usage}

\subsubsection{Space Heating and Cooling Loads}

Calculations were made of the expected loads for space heating and cooling, domestic water heating, and miscellaneous electrical uses at each of the six BREAKTHROUGH sites. This information was needed to determine the approximate size of the total energy plants, the applicable energy rate schedules, the availability of appropriate system components, the differential in first costs, and the amount of space needed for the plant on the site. The housing system producers that are to build on each site, as well as the number of dwelling units that each will build, have been identified.

However, the kind of materials to be used in the exterior envelopes, the amount of window area, and the area of the exposed walls have not been detailed sufficiently to permit a good calculation of the heating and cooling loads. Therefore, the heating and cooling loads for the dwelling units were approximated by assuming that the constructions would meet the heat transmission factors and window areas cited in the Evaluation Criteria. These calculations were based on the following assumptions:

(a) floor area $-1050 \mathrm{sq}$ ft $\left(42^{\prime} \times 25^{\prime}\right)$

(b) ceiling height- $8 \mathrm{ft}$

(c) indoor conditinns $-75^{\circ} \mathrm{F}$

(d) exterior wall U value - $0.2 \mathrm{Btu} / \mathrm{hr}, \mathrm{ft}^{2},{ }^{\circ} \mathrm{F}$

(e) ratio of glass area to total exterior surface wall area - $30 \%$

(f) window $U$ value $-1.1 \mathrm{Btu} / \mathrm{hr}$, ft ${ }^{\circ} \mathrm{F}$ for single family detached $0.55 \mathrm{Btu} / \mathrm{hr}, \mathrm{ft}^{2}$, ${ }^{\circ} \mathrm{F}$ for other types of dwellings

(g) roof U value - $0.1 \mathrm{Btu} / \mathrm{hr}, \mathrm{ft}^{2}{ }^{\circ} \mathrm{F}$

(h) floor U value - $0.1 \mathrm{Btu} / \mathrm{hr}, \mathrm{ft}^{2},{ }^{\circ} \mathrm{F}$

(i) air change rate per hour - 1 for single family detached 0.75 for other types of dwellings.

Since the individual dwelling units will be stacked and superimposed over each other in a variety of ways that are only partially known at this time, some simplifying assumptions were made about the number of exposed walls and other components that would comprise the heat transmission load. The six typical dwellings are characterized as follows : 
Type No. Number and types of exterior surfaces

1

1 wa11

2 walls

3
4

5

6

2 walls and roof

3 walls

4 walls, roof and floor
Type of dwe 11 ing

Multiple family high-rise

central section of the building

Multiple family high-rise

end sections of the building

Same as 1 for the top floor

Same as 2 but for the top floor

Multiple family 1ow-rise and single

family attached

Single family detached

The heating and cooling loads for each of these six typical dwelling units were first calculated for the following standard conditions. These calculated values are summarized below:

\begin{tabular}{|c|c|c|c|}
\hline & & $\begin{array}{l}\text { eating } \\
\text { eason } \\
\end{array}$ & $\begin{array}{l}\text { Cooling } \\
\text { Season }\end{array}$ \\
\hline $\begin{array}{l}\text { Outdoor temperature, }{ }^{\circ} \mathrm{F} \\
\text { Outdoor wet-bulb temp } \\
\text { Solar heat gain through } \\
\text { windows, Btu/hr, ft }\end{array}$ & ${ }^{\circ} \mathrm{F}$ & $\begin{array}{l}0 \\
- \\
-\end{array}$ & $\begin{array}{l}94 \\
78 \\
40\end{array}$ \\
\hline Dwelling Type & Heating 1oad & (Btu/hr) & Cooling load (Btu/hr) \\
\hline $\begin{array}{l}1 \\
2 \\
3 \\
4 \\
5 \\
6\end{array}$ & $\begin{array}{l}15,000 \\
21,000 \\
23,000 \\
38,000 \\
25,000 \\
55,000\end{array}$ & & $\begin{array}{l}12,000 \\
18,000 \\
20,000 \\
26,000 \\
22,000 \\
35,000\end{array}$ \\
\hline
\end{tabular}

These standard heating and cooling loads were adjusted for each site by using a multiplier involving the monthly heating and coolirg degree-days at the site to obtain the total heating and cooling requirements on a month-by-month basis. The above values were also used to determine the maximum demand for heating or cooling for all the dwelling units on a site using a multiplier that incorporated the minimum and maximum temperatures that occurred during each month. Table 4 is a summary of the monthly degree-days and Table 5 is a summary of the maximum and minimum monthly temperatures for the six sites, that were used in the above calculations. 


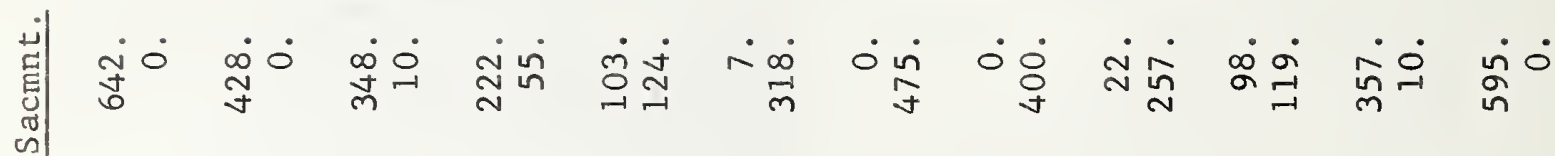

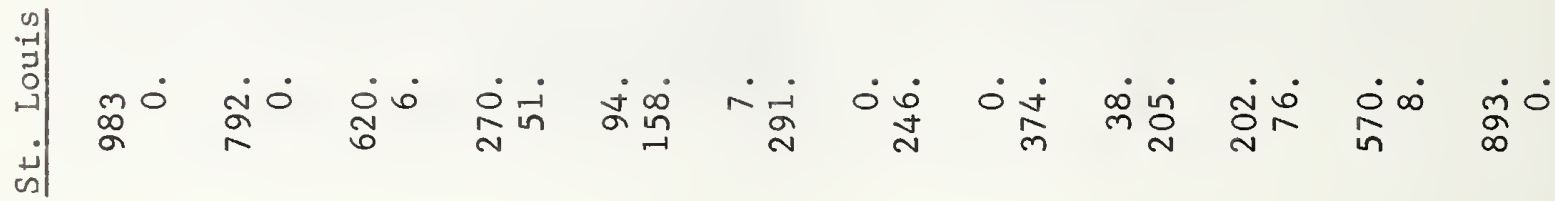

竒

䜌

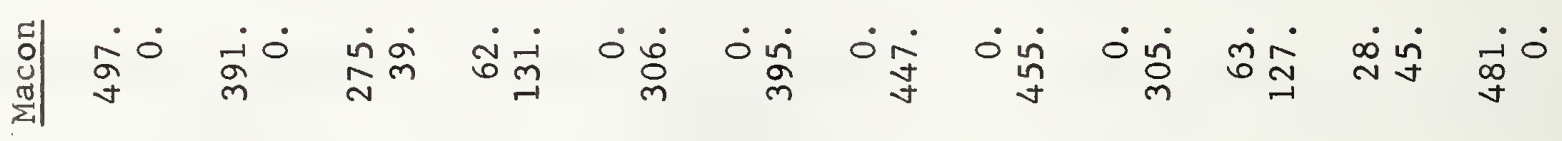

敬

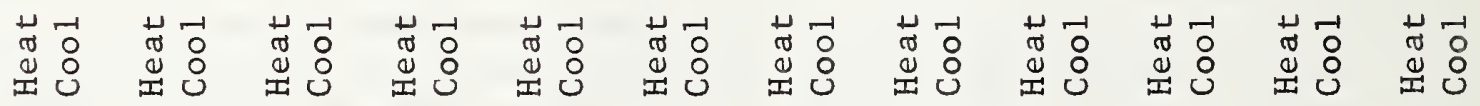

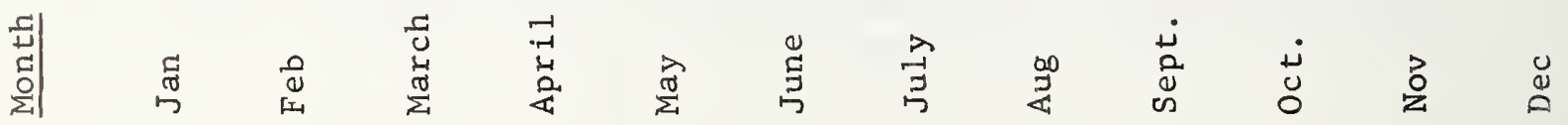




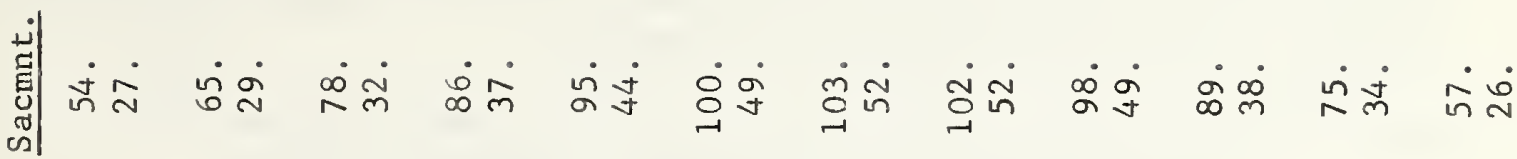

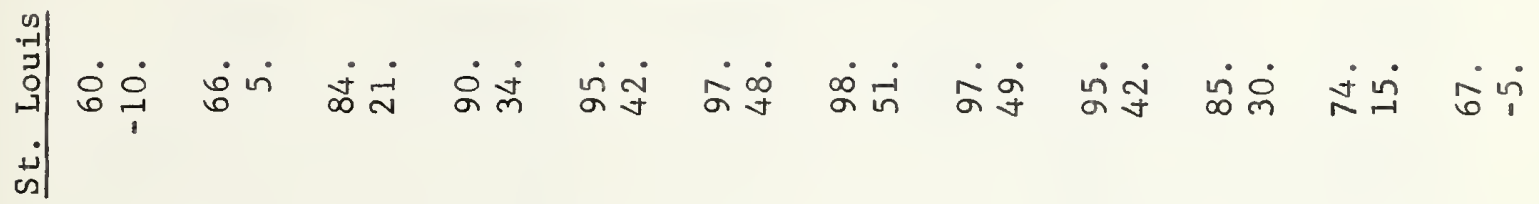

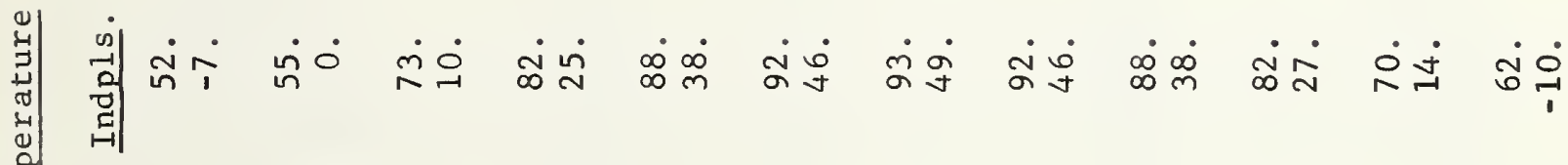

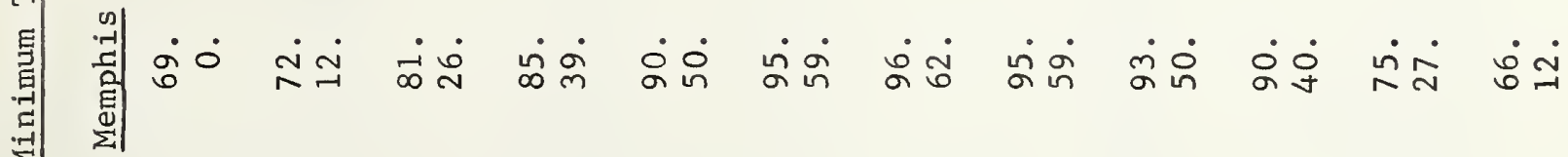

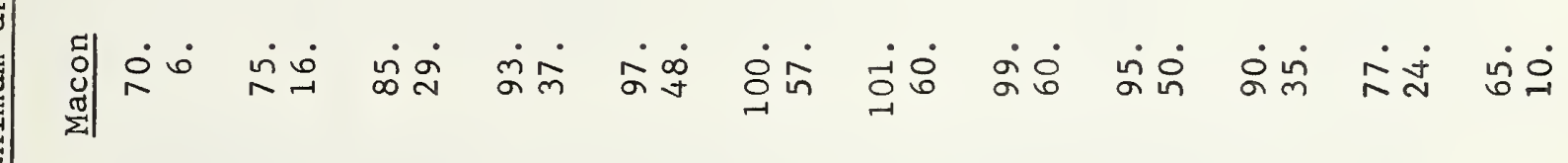

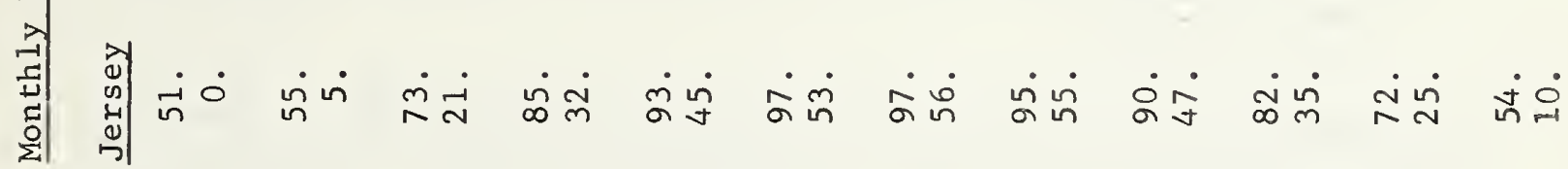
in क्य

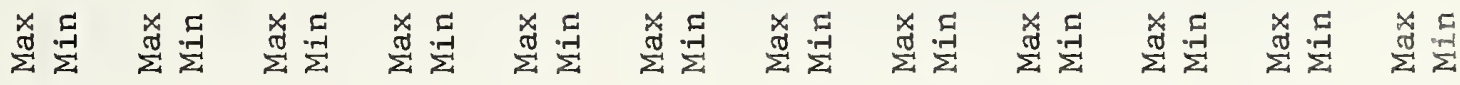

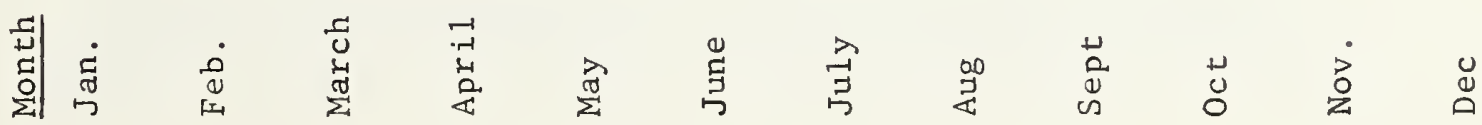


By examining the annual electricity and domestic hot water usage profiles reported in various publications [1-5] $\frac{1}{3}$ the following usages and demands of electricity and domestic hot water were selected as typical, including the effects of diversity.

Table 6. Electrical and Domestic Hot Water Demand and Usage per Dwelling Unit (No electric cooking included)

\begin{tabular}{|c|c|c|c|c|}
\hline Month & $\begin{array}{l}\text { Miscellaneous } \\
\text { elect. use (KWH) }\end{array}$ & $\begin{array}{l}\text { Demand } \\
\mathrm{KW} \\
\end{array}$ & $\begin{array}{l}\text { Hot Water } \\
\text { Use (KWH) } \\
\end{array}$ & $\begin{array}{c}\text { Demand } \\
\mathrm{KW} \\
\end{array}$ \\
\hline January & 670 & 1.3 & 611 & 1.3 \\
\hline February & 605 & 1.4 & 560 & 1.7 \\
\hline March & 595 & 1.3 & 609 & 1.7 \\
\hline April & 576 & 1.2 & 471 & 1.3 \\
\hline May & 594 & 1.2 & 549 & 1.3 \\
\hline June & 648 & 1.4 & 430 & 1.3 \\
\hline July & 818 & 1.5 & 349 & 0.8 \\
\hline August & 744 & 1.4 & 413 & 0.5 \\
\hline September & 648 & 1.4 & 452 & 0.8 \\
\hline October & 596 & 1.2 & 495 & 1.3 \\
\hline November & 576 & 1.3 & 573 & 1.3 \\
\hline December & 669 & 1.3 & 573 & 1.3 \\
\hline
\end{tabular}

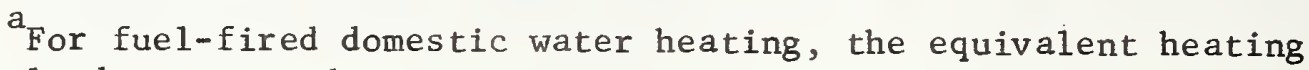
loads were used.

By multiplying the values shown in Table 6 by the number of dwelling units at each site, the total site demand and monthly consumption of energy for the miscellaneous electricity and hot water were obtained.

The calculated and selected values for monthly usage and demand of energy for space heating and cooling, domestic hot water, and misce1laneous electrical loads were collected into an annual energy usage profile for each site. An example of such a profile for the Jersey City site is shown in Table 7 .

I/ numbers in brackets refer to references at end of text. 


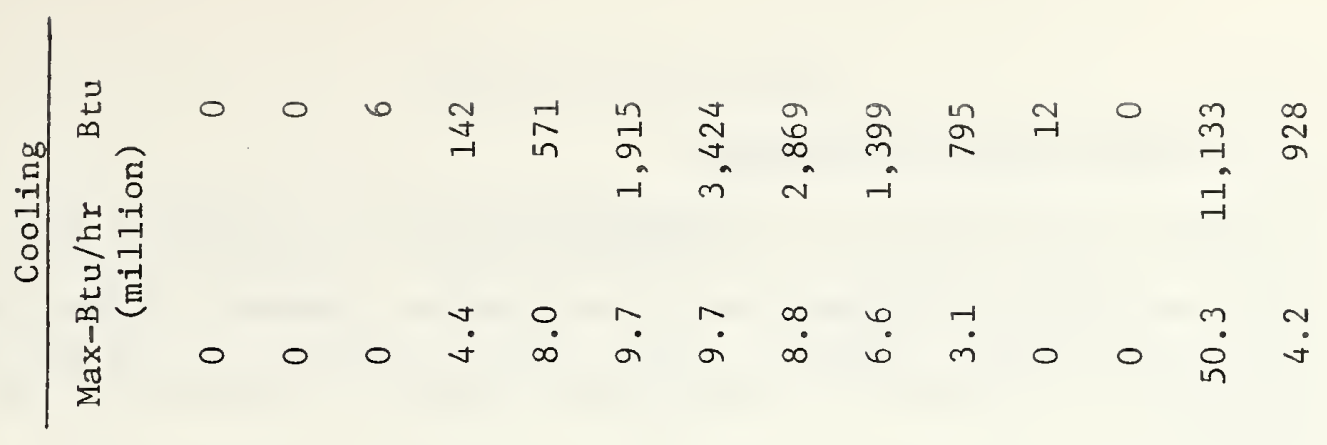

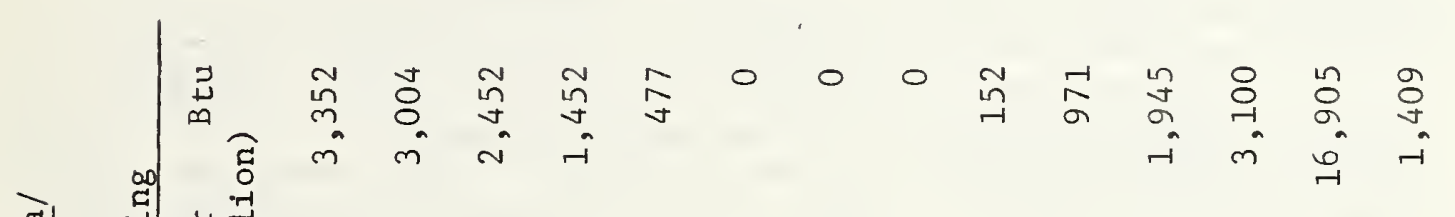

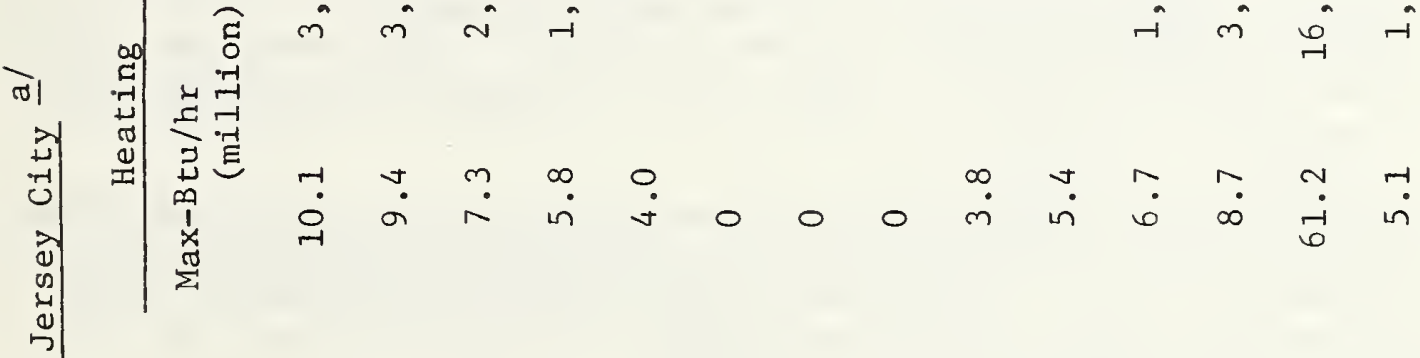

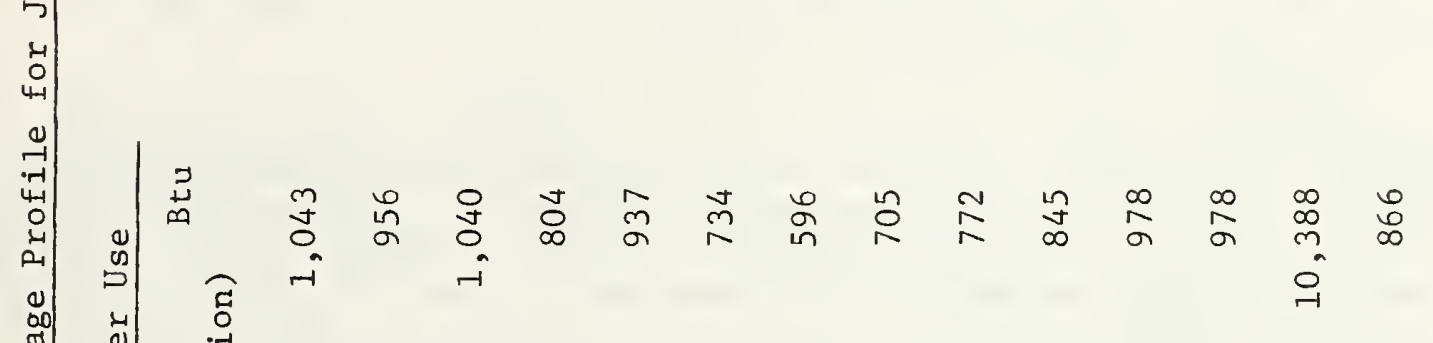

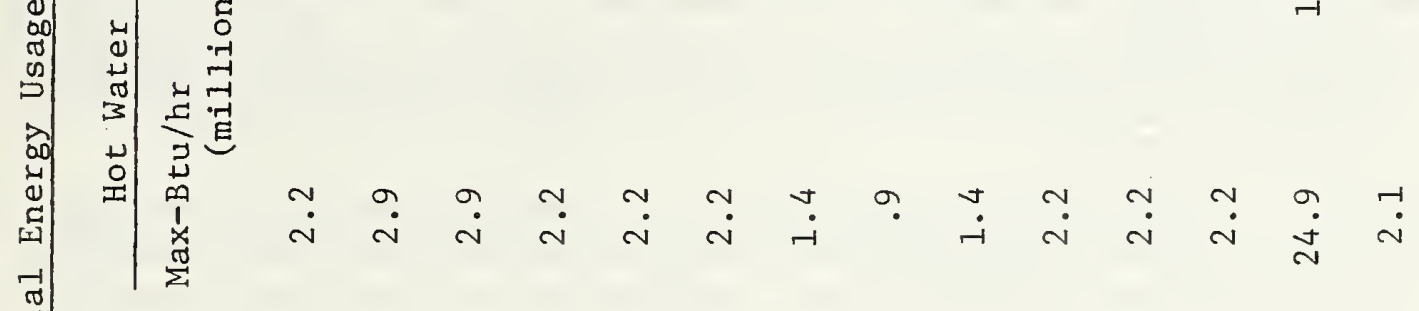

离

$\dot{\sim}$

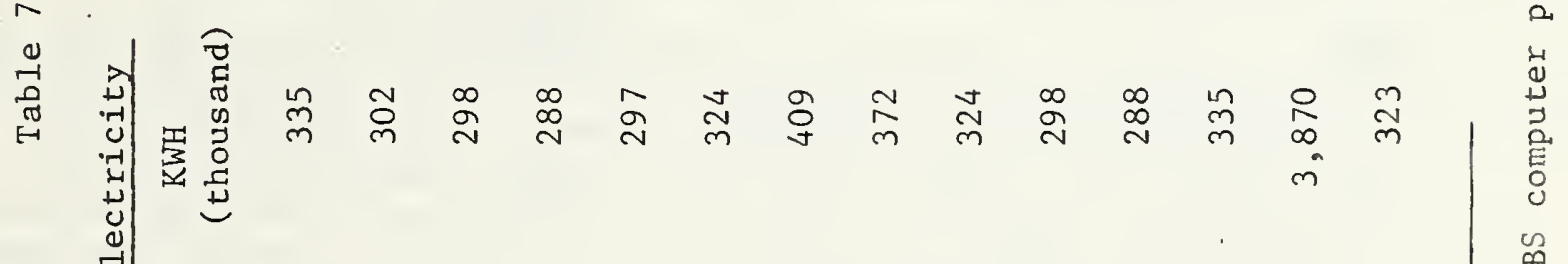

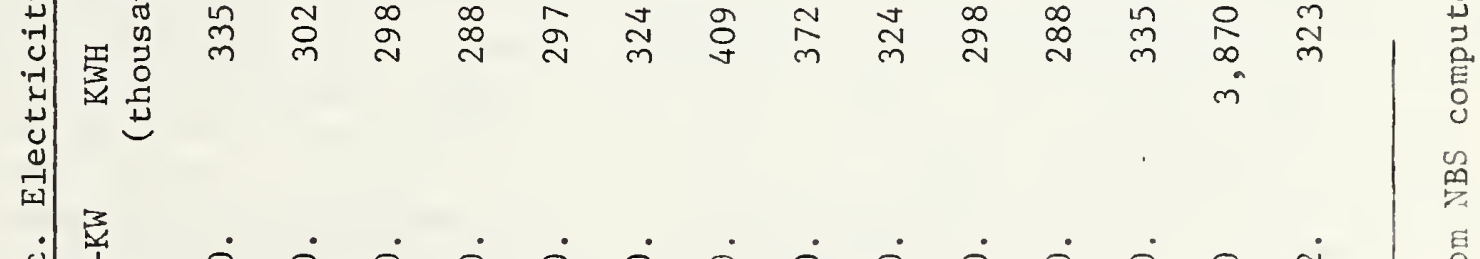

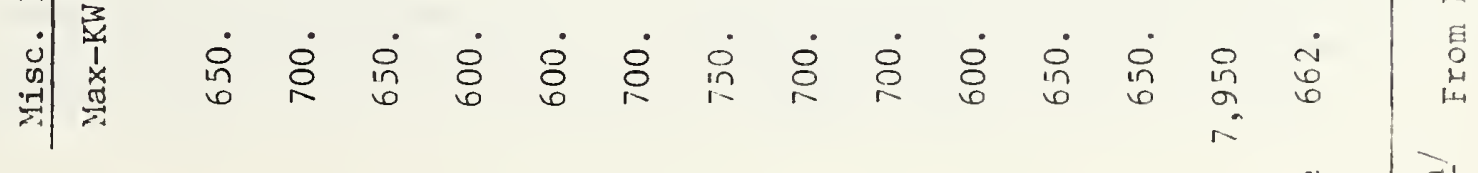

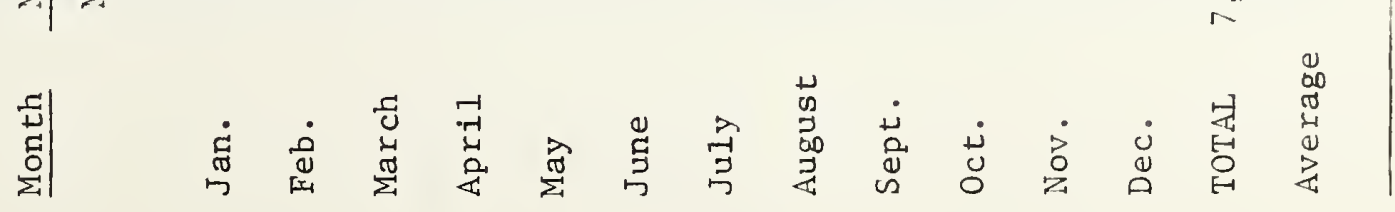




\subsubsection{Energy System Simulation}

The energy requirement for a BREAKTHROUGH site is different for different types of energy utilization systems. Considered in this report were eight different energy utilization systems. These comprise four different types of total energy systems, two all-electric systems, and two central conventional systems, as illustrated in Fig. 1 .

System 1 is a total energy system in which an engine-generator provides electricity for miscellaneous electric power needed for the household use and a boiler provides heat for domestic hot water, space heating, and the heat required for the absorption refrigeration air conditioning equipment, to supplement the waste heat obtained from the engine-generator. It was assumed for this system that $50 \%$ of waste heat from engine jacket water and from engine exhaust could be reclaimed.

The fuel thermal efficiencies for the boiler and the engine generator were assumed to be $70 \%$ and $25 \%$ respectively. The coefficient of performance for the absorption cooling system was assumed to be 0.6 . The condenser heat of the absorption air conditioning unit was rejected to the ambient without recovery.

System 2 is another total energy system in which engine-driven compressors were used to provide the energy required for the space cooling instead of the absorption unit of System 1. All the efficiency values for the system were assumed the same as for System 1 except that the engine compressor efficiency was $30 \%$ and the coefficient of performance for the compressor cooling was 2.75 . Up to $50 \%$ of waste heat from the engine generators and the engine compressors was assumed to be available for domestic water and space heating.

System 3 is the combination of Systems 1 and 2 where space cooling energy is shared by absorption units and engine compressor units. Calculations were performed for combinations in which the space cooling by the engine compressor was assumed to be $0.2,0.4,0.6$, and 0.8 of the total cooling requirement, and the remainder of the air conditioning was accomplished by an absorption system.

System 4 is a Stair patented heat conservation concept applied to the total energy system to make more efficient use of waste heat from the engine generator during the summer. The heat conservation system consists of a water-source heat pump in each dwelling unit which exchanges heat with a closed water loop around the site operating in a temperature range of $60^{\circ} \mathrm{F}$ to $90^{\circ} \mathrm{F}$. During the summer the loop water temperature is raised above $90^{\circ} \mathrm{F}$ because most of the heat pump units are rejecting heat to the water. The waste heat from the engine generator which supplies electricity to each of heat pumps, 


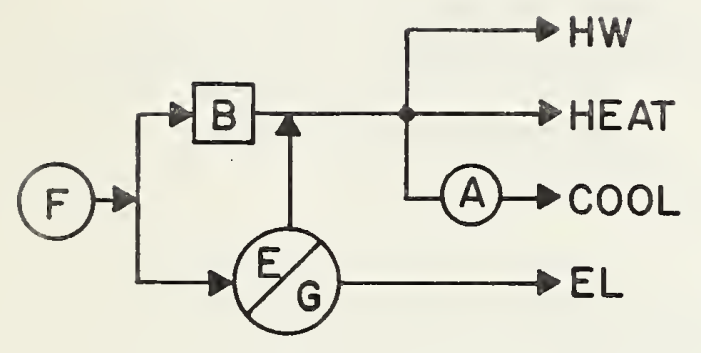

1 TOTAL ENERG WITH ABSORPTION CO()I, IN:

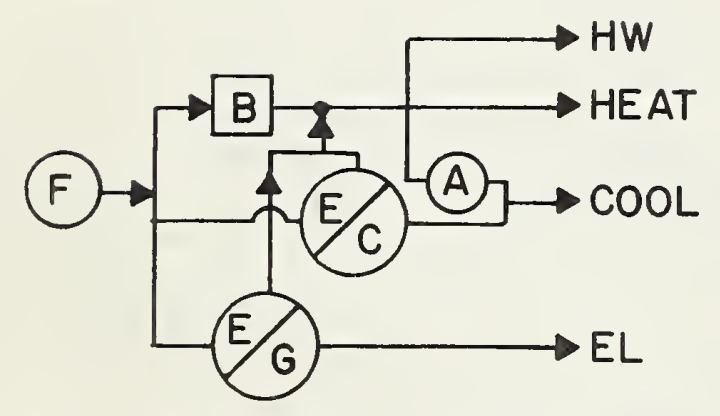

3 TOTAL ENERGY WITH CENTRIFUCAL AND ABSORPTLON COOLING

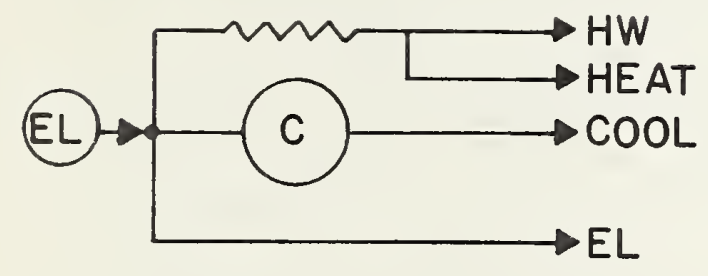

5. ALL, ELECTRIC WITH RESISTANCE HEATING AND) CENTRIFUGAI COOLING

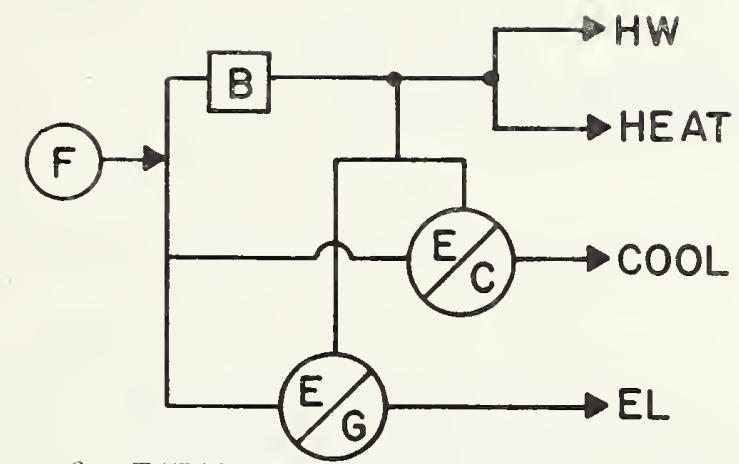

2 TO'TAL ENERGY WTTH CENTRIFUGAL COLING

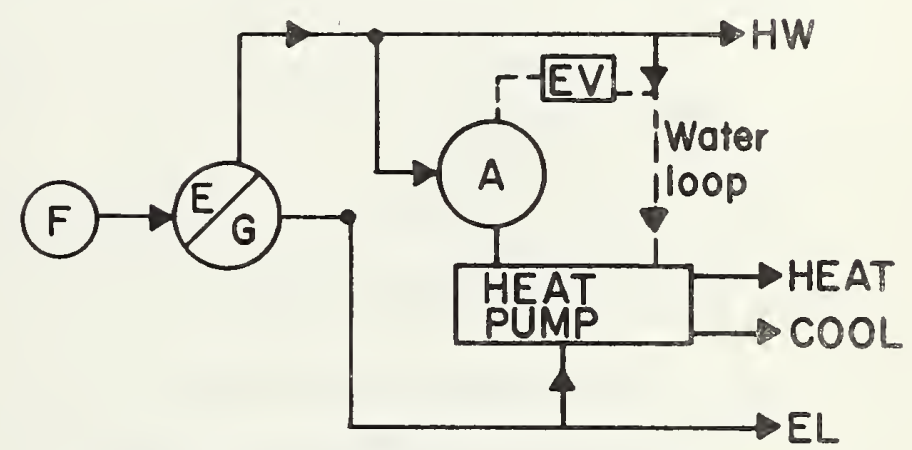

4 TOTAL ENERGY WITH "STAIR" PATENTED HEAT CONSERVATION LOOP

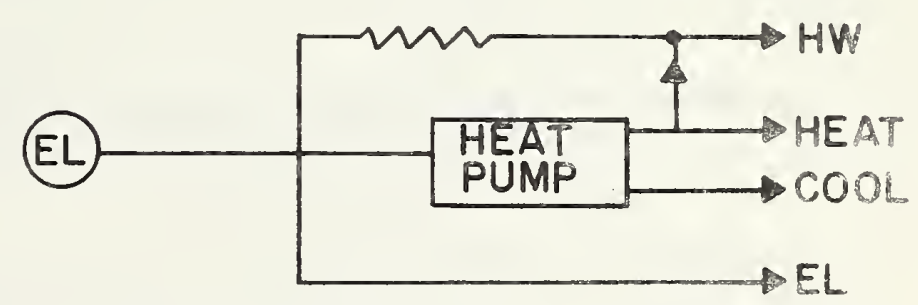

6 ALL ELECTRIC HEAT PUMP WITH SUPPLEMENTAL RESISTANCE HEATING 


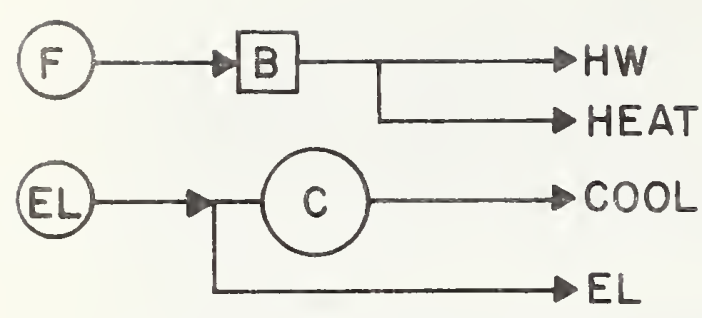

7 PURCHASED UTLLITIES, FUEL EIRED HEATING, ELECTRIC COOLING

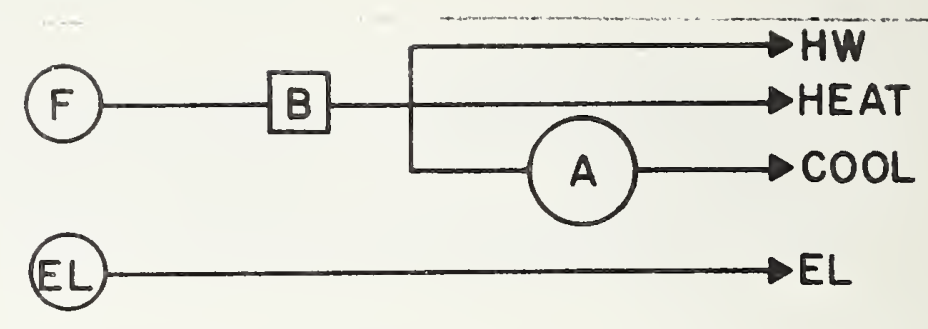

8 PURCHASED UTILITIES, FUEL FIRED HEATING AND COOLING

\section{LEGEND - FIGURE 1}

F - fue 1

B - boiler

E/G - engine - or turbine-driven generator

A - absorption cooler

HW - domestic hot water

HEAT - space heating (steam or hot water)

COOL - chilled water

EL - electricity

E/C - engine - or turbine-driven centrifugal cooler

C - motor-driven centrifugal cooler

EV - evaporative cooler 
water circulating pumps, and for micellaneous use can be utilized to operate an absorption unit for cooling the water in the loop. If the absorption cooling capacity is not adequate, additional cooling may be supplied by an evaporative cooler as indicated in the figure. During the winter, the water loop temperature falls because most of the heat pumps are taking heat away from the water. Waste heat from the engine generator is then used to heat the water in the loop. Any given heat pump unit may be operating in either a heating or cooling cycle in this system.

The performance simulation calculation for system 4 was carried as follows :

1. Water flow rate in loop, GPM = $2.5 x$ Maximum Cooling Load of the year for a given site

2. Assume the entering water temperature to the heat pumps.

3. Calculate the total electrical energy required for operating heat pumps as function of water temperature entering the system.

4. Calculate the net heat exchange of the heat pumps with the water to determine the water temperature change across all the heat pumps.

5. Calculate the cooling capacity of the absorption unit as a function of the waste heat generated by the engine-generator.

6. Make heat balance calculation for the loop water heat exchange with the generator waste heat: cooling during the summer and heating during winter.

7. If the loop water temperature exceeds $90^{\circ} \mathrm{F}$ during the summer in spite of the absorption refrigeration, it will have to be cooled by an evaporative cooler to $90^{\circ} \mathrm{F}$ and repeat the calculations 2- 6 by assuming the water temperature entering the heat pump to be $90^{\circ} \mathrm{F}$.

8. If the loop water temperature cannot be brought up to $60^{\circ} \mathrm{F}$ by the engine waste heat during winter, a supplementary heater will be needed to bring it up to $60^{\circ} \mathrm{F}$ and the calculations 2-6 should be repeated by assuming the entering water temperature to be $60^{\circ} \mathrm{F}$.

9. If the loop water temperature falls between $60^{\circ} \mathrm{F}$ and $90{ }^{\circ} \mathrm{F}$, but differs from what was assumed at step 2, iterate the calculation procedure 2-6 until the assumed value is to within $1^{\circ} \mathrm{F}$ of the resulting value.

System 5 is a conventional all-electric system where heating energy is provided by resistance heaters and cooling by motor-driven compressors.

System 6 is a heat pump system where the major portion of the space heating and cooling was accomplished by individual air-to-air heat pumps. In order to calculate the energy requirement for the heat pump system it was assumed that the system was in the cooling cycle during the months of May, June, July, August and September, and the rest of the year was in the heating cycle. 
Systems 7 and 8 are conventional systems utilizing electrical energy from the municipal system and fossil fuel for heating functions. System 7 uses electricity for the miscellaneous electric demand and for driving the air conditioning compressors, and fuel for the space heating and domestic hot water. System 8 replaces the motordriven compressor cooling system of System 7 by an obsorption cooling system.

A computer program was prepared to calculate the monthly and annual energy usage and the monthly and annual energy cost for each of the eight energy systems described above, for the BREAKTHROUGH sites at Jersey City, Macon, Memphis, Indianapolis, Sacramento and St. Louis. In addition, the program calculated the total waste heat generated, the amount of waste heat recovered, and the supplementary heat required.

Table 8 summarizes the anticipated annual energy requirements for the several systems when used at the six sites. The following conclusions are indicated by the data in Table 8:

a) The Stair heat conservation loop, combined with a total energy system has the highest energy requirements at most sites. In this system the waste heat was used in an absorption air conditioning system to cool the loop water in the summer time, but an evaporative cooler was also required to attain adequate cooling.

b) Of the more conventional total energy systems, the system using $100 \%$ absorption cooling had the highest energy requirement.

c) The combination of absorption cooling and compression cooling with minimum energy usage fell in the range of 60 to 80 percent compression cooling. This ratio could change somewhat depending on what other uses were made of waste heat.

d) The heat pump system had the lowest energy requirement at the site. It should be noted that about twice as much energy is dissipated in the cooling water at the power generating station as that represented at the point of usage. However, if the on-site energy usage by the heat pump shown on Table 8 is multiplied by three, the result is in range of the values for the several total energy systems.

Table 9 and Figure 2 compare the energy cost for the same systems identified in Table 8 . Figure 2 shows graphically the energy cost of the various systems for Jersey City. Three sources of energy are considered in Table 9: gas, oil, and electricity. Figure 3 shows the comparative costs in graphical form with mixed combinations of absorption and engine-driven centrifugal compressors. Figure 3 was plotted from the NBS computer print out. The summary indicated the following conclusions:

a) The total energy system using 60-80\% compression cooling and 40-20\% absorptive cooling is the most economical in every case. This system is from 15 to $30 \%$ more economical than a system using $100 \%$ absorption cooling. 


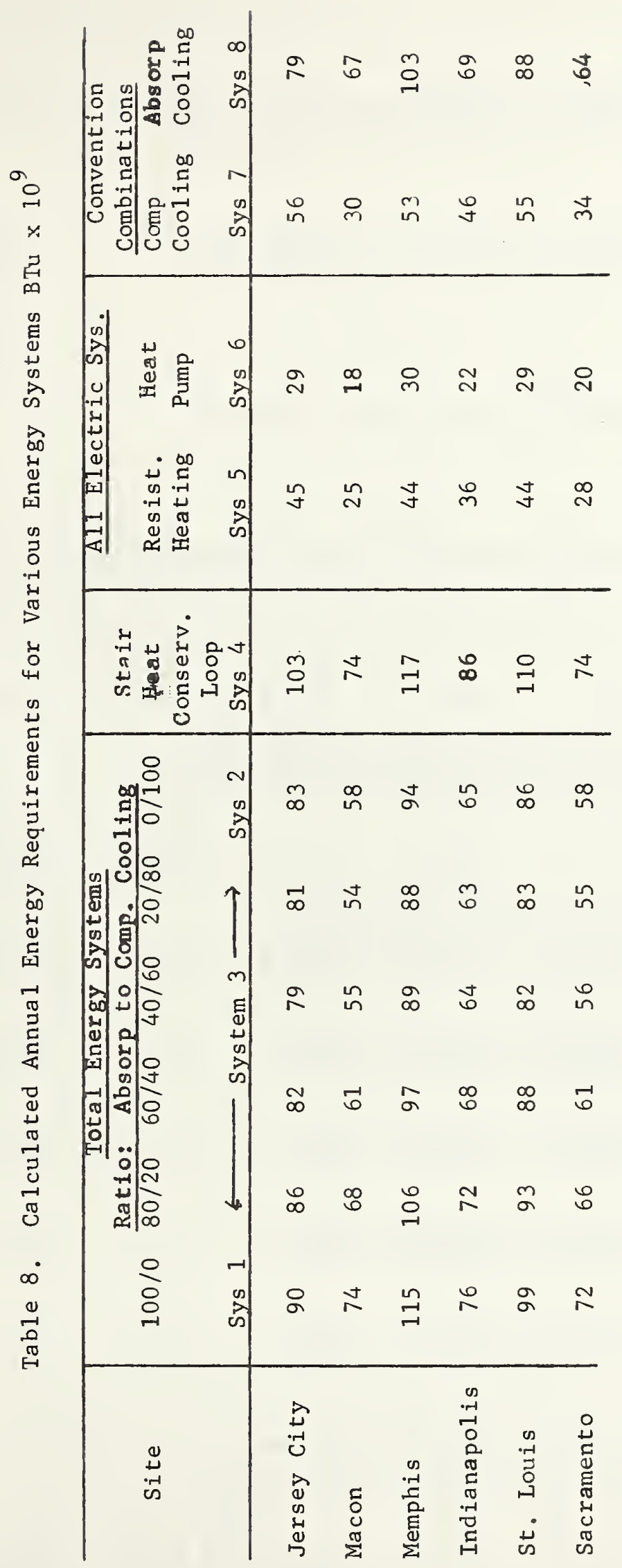




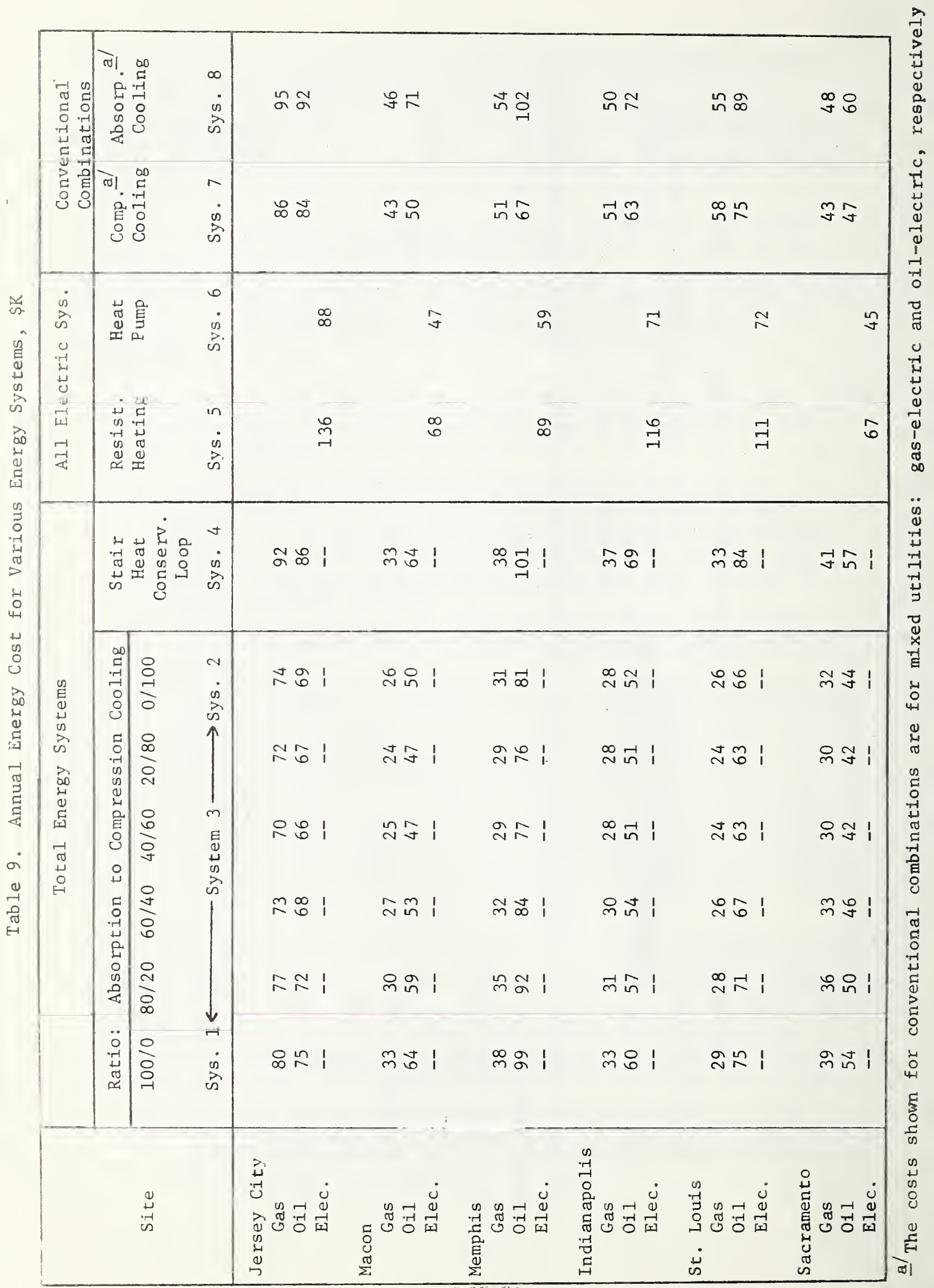




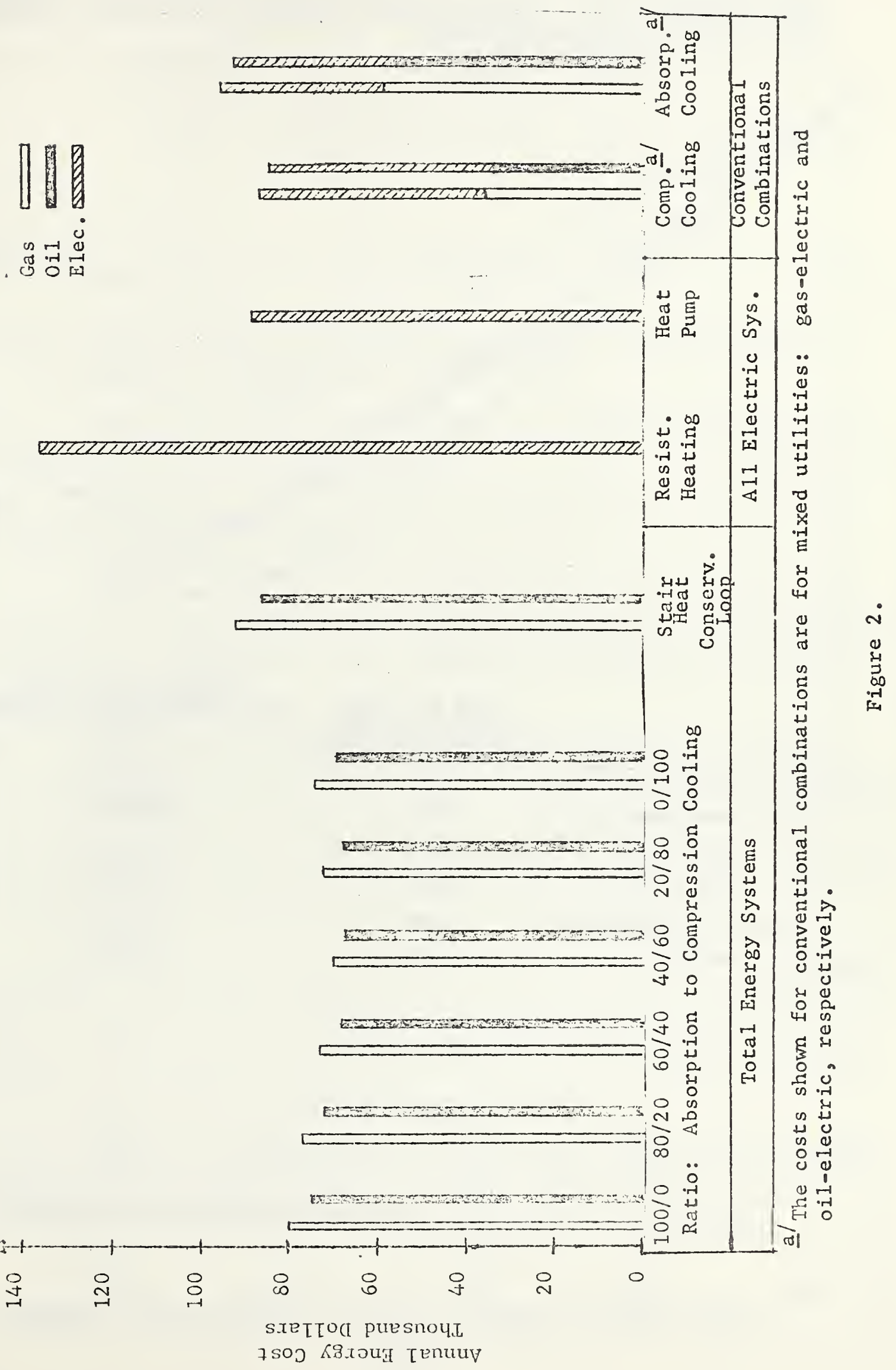


COST COMPARISONS OF T.E. SYSTEMS EMPLOYNG ALL ABSORPTION COOLING. ALL COMPRESSOR COOLNG AND MIXED ABSORPTION COMPRESSOR COOLING.

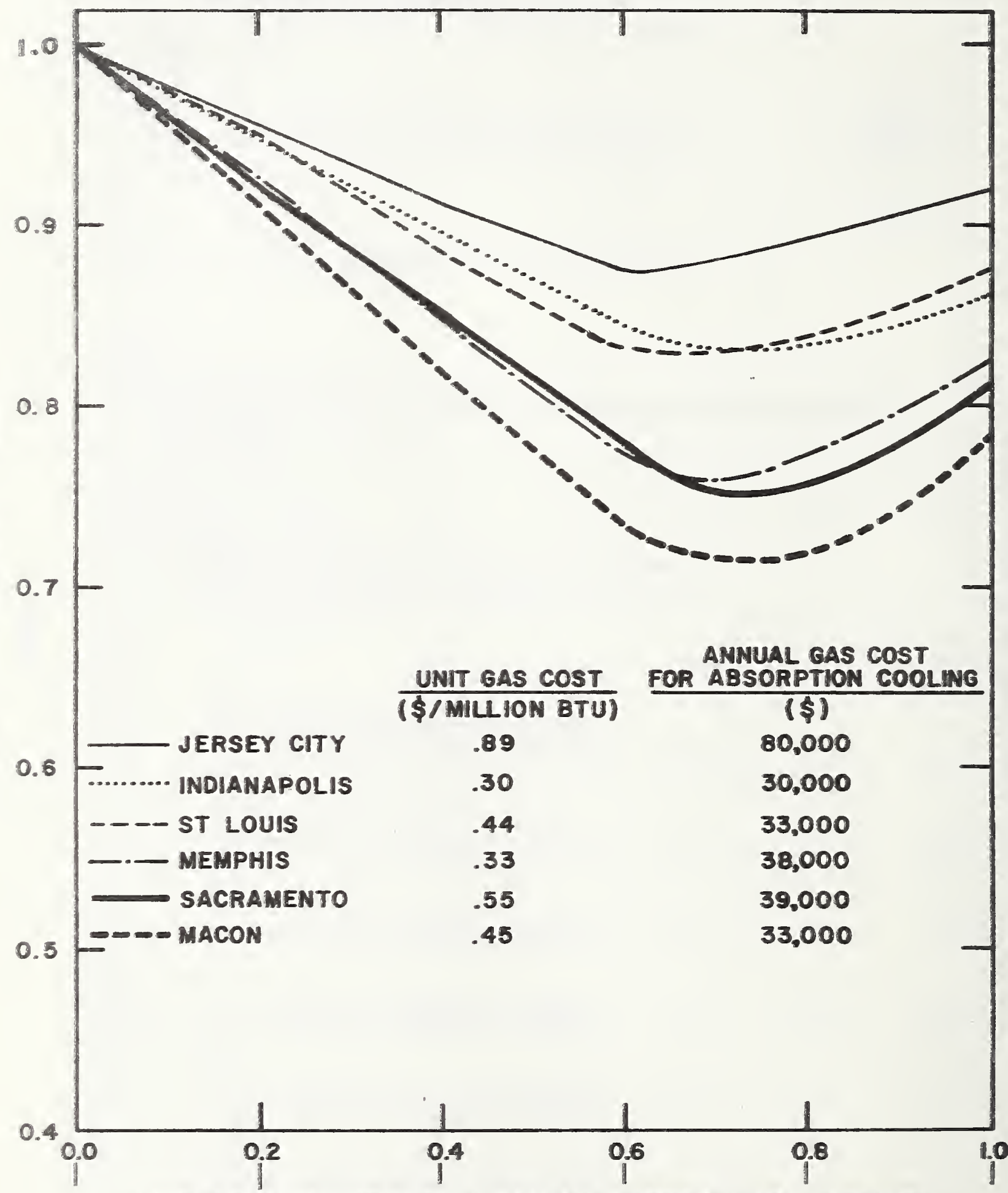

FRACTION OF COOLING LOAD BY COMPRESSOR COOLING
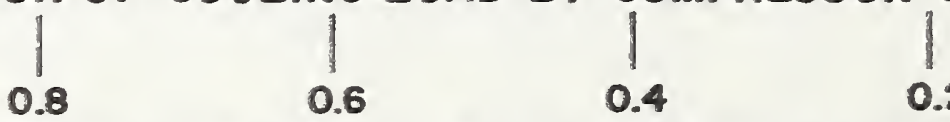

0.2

FRACTION OF COOLING LOAD BY ABSORPTION COOLING Figure 3 
b) The most economical total energy system may save from 20 to $60 \%$ of the energy cost of a mixed utility combination where electricity and gas are purchased from separate utilities.

c) The energy cost of an all-electric system using heat pumps is only 5 to $15 \%$ higher than the energy cost for the best of the mixed utility combinations at four of the six sites.

\subsection{Energy Cost Data}

Energy cost information was obtained for the six BREAKTHROUGH sites from the following sources:

1. Electric rates: Memphis Light, Gas, and Water Division, City of Memphis, for that city. Federal Power Commission National Electric Rate Book for the other cities.

2. Natural gas rates: Memphis Light, Gas, and Water Division, City of Memphis, for that city. American Gas Association Rate Service for the other cities.

3. Fuel oil rates: Fue1 oil rates: Quoted prices from local fuel oil dealers in each city.

In every BREAKTHROUGH location the electric and gas utilities have established several rate schedules which apply to residential, commercial and industrial uses; in general, lower unit costs accompany higher energy consumption. An example of a rate schedule (for Memphis) is reproduced on the following pages.

For purposes of computing monthly and annual energy costs at each site, those rate schedules providing the lowest cost for energy and for which the BREAKTHROUGH projects appeared qualified, were used. This information for gas is summarized in Fig. 4 in a plot of unit cost for energy vs. energy consumed. The cost reflects both the charge for energy and the demand charge (if any). The unit cost over the range of energy consumption is nearly constant. This data was used in the computer program described in Section 4.3 of this report and is listed in Table 10.

A similar graph (Fig. 5) for electric unit cost (including energy charge and demand charge) shows that the unit cost is not constant; the range of unit costs is also included in Table 10. The lower end of the range in Table 10 applies to an all-electric system using heat pumps or resistance heating. The upper end of the range applies to the conventional system with absorption cooling, and to the conventional system with motor-driven refrigerating units in the heating season.

Finally, fuel oil costs are summarized in Table 10. These costs are not dependent on the amount consumed (at least in the range of size of BREAK THROUGH facilities) when the fuel is delivered in bulk to a central utility plant. 


\title{
MEMPHS LIGHT, GAS AND WATER DIVISION CITY OF MEMPHIS
}

\section{ELECTRIC SERVICE}

\author{
Schedule $\mathrm{CO}-4$
}

\section{GENERAL POWER RATE}

\section{AVAILABILITY}

Available to commercial, industrial, governmental and other customers whose requirements are limited to firm power, except those to whom service is available under the Residential or Outdoor Lighting Rate Schedules.

\section{CHARACTER OF SERVICE}

Alternating current, single or three-phase, 60 cycles. Power sold under A and B below will be delivered at a voltage available in the vicinity or agreed to by Division. Power sold under $\mathrm{C}$ below will be delivered at transmission voltage of $161 \mathrm{kv}$ or, if such transmission voltage is not available, at the highest voltage available in the vicinity, unless at the customer's request a lower standard voltage is agreed upon.

\section{MONTHLY RATE}

A. If the customer's demand for the month and its contract demand, if any, are each less than 50 kilowatts:

DEMAND CHARGE:

First 10 kilowatts of demand per month, no demand charge

Excess over 10 kilowatts of demand per month, at $\$ 1.00$ per kilowatt.

ENERGY CHARGE:

First $200 \mathrm{KWH}$ consumed per month@2.90 $\varnothing$ per KWH.

Next 300 KWH consumed per month@1.70 $\$$ per KWH.

Next 1,000 KWH consumed per month@1.20ф per KWH.

Next 12,500 KWH consumed per month@0.86 per KWH. Additional energy consumed per month @ $0.57 \phi$ per KWH.

B. If either the customer's demand for the month or its contract demand is at least 50 kilowatts but not more than 5,000 kilowatts:

\section{DEMAND CHARGE:}

First 100 kilowatts of demand per month at $\$ 1.00$ per kilowatt

Excess over 100 kilowatts of demand per month at $\$ 1.15$ per kilowatt

ENERGY CHARGE:

First 14,000 KWH consumed per month@0.82\& per KWH.

Next 26,000 KWH consumed per month@0.56 $\not$ per KWH.

Next 60,000 KWH consumed per month@0.44\% per KWH.

Next 400,000 KWH consumed per month@0.33 9 per KWH. Additional energy consumed per month@0.31\& per KWH. 
C. If either the customer's demand for the month or contract demand is greater than 5,000 kilowatts:

\section{DEMAND CHARGE:}

First 75,000 kilowatts of demand per month at $\$ 1.15$ per kilowatt.

Excess over 75,000 kilowatts of demand per month at $\$ 1.05$ per kilowatt.

Additional charge for any demand in excess of customer's contract demand at $\$ 1.15$ per kilowatt per month.

\section{ENERGY CHARGE:}

First 20,000,000 KWH consumed per month @2.85 mills per KWH.

Next 30,000,000 KWH consumed per month@2.80 mills per KWH. Additional energy consumed per month@ 2.75 mills per KWH.

\section{FACILITIES RENTAL: (Charges applicable under C above)}

No facilities rental charge is applicable for delivery at $161 \mathrm{kv}$. For delivery at less than $161 \mathrm{kv}$, the customer will pay, in addition to all other charges hereunder, a facilities rental charge of 15 cents per $\mathrm{kw}$ per month for the first 10,000 kw of the customer's contract demand and 5 cents per kw per month for the portion of coniract demand which is in excess of 10,000 $\mathrm{kw}$, except that, for delivery at less than $46 \mathrm{kv}, 20$ cenis shall apply in lieu of 15 cents in the first portion of said facilities rental charge.

\section{ADJUSTMENTS}

1. Under A, B and C above, the customer's bill for each month will be increased or decreased by 0.01 mill per kwh for each 0.01 mill or major fraction thereof by which TVA's fossil and nuclear fuel expense per kwh sold by TVA as determined by TVA from its records exceeded or was less than 1.45 mills, respectively, during the most recently completed fiscal year ending with June 30.

2. Under A above when the customer's demand is 10 kilowatts or less, the customer's bill for each month will be increased or decreased by 0.03 mill per kwh for each 1 cent or major fraction thereof by which the sum of (a) TVA's interest charges to operations during the most recently completed fiscal year ending with June 30 and (b) the return on the appropriation investment that TVA is obligaied to pay for the fiscal year immediately following said most recently completed fiscal year, divided by the sum of the monthly billing demands of power sold by TVA in said most recently completed fiscal year as determined by TVA from its records exceeded or was less than 40 cents, respectively.

3. Under $B$ and $C$ above and under $A$ above when the customer's demand exceeds 10 kilowatts, the customer's bill for each month will be increased or decreased by 1 cent per kw of demand for each 1 cent or major fraction thereof by which the sum of (a) TVA's interest charges to operations during the most recently completed fiscal year ending with June 30 and (b) the return on the appropriation investment thai TVA is obligated to pay for the fiscal year immediately following said most recently compleied fiscal year, divided by the sum of the monthly billing demands of power sold by TVA in said most recently completed fiscal year as determined by TVA from its records exceeded or was less than 40 cents, respectively. 
Any adjustment made pursuant to paragraphs 1,2 or 3 above shall be effective for 12 consecutive montlly billings beginning with the first bill rendered from meter readings taken after Augusi 1 of the calendar year in which each such fiscal year ends.

\section{MINIMUM BILL}

The monthly bill under $A$ and $B$ above shall in no case be less than $\$ 1.50$ plus an additional $\$ 0.50$ per kilowatt for the excess over 10 kilowatts of the highest demand during the preceding 12 months. Under $\mathrm{C}$ above, the monthly bill for demand, energy and adjustments shall in no case be less than $\$ 1.30$ per kilowatt of the contract demand or any higher demand established during the preceding 12 months, but said $\$ 1.30$ shall be adjusted in the same manner as provided in Adjustment 3 above in respect to the customer's billing demand. Division may require minimum bill higher than those stated above.

\section{SEASONAL SERVICE}

Customers who contract for service on a seasonal basis shall be limited to $1,500 \mathrm{kw}$ and shall pay the above rates plus 10 percent of the bill computed after any adjustments are applicd. For such customers the "Minimum Monthly Bill" provided above shall not apply. Instead such customers shall pay a minimum monthly bill of $\$ 5.00$ so long as service is cut in, shall pay a minimum annual bill which shall in no case be less than $\$ 6.00$ per kilowatt of the maximum demand established, and shall pay in addition the actual cost of cut-ins and cut-outs in excess of one of each per year.

\section{CONTRACT REQUIREMENTS}

Customers whose demand exceeds 20 kilowatts will be required to execute contracts for an initial term of at least one year. If the customer requires in excess of 5,000 kilowatts, the contract shall be foi an initial term of at least five years. If the customer requires in excess of 15,000 kilowatts, any renewal or extension of the initial contract shall also be for a term of at least five years. The customer shall contract for his maximum requirements and Division shall not be obligated to furnish power in greater amount at any time than the customer's contract demand. The contract with any customer may provide for minimum charges higher than those stated above. If the customer uses any power other than that supplied by Division under this rate, the contract may include other special provisions. The rate schedule in any power contract will be subject to modification at any time upon agreement by Division and TVA.

\section{DETERMINATION OF DEMAND}

Division will measure the demands in kilowatts of all customers having a connected load in excess of 10 kilowatts. The demand for any month shall be the highest average load measured in kilowatts during any 30 consecutive minute period of the month. However, if 85 percent of the highest average kva measured during any 30 consecutive minute period for any load of 5,000 kva or less (or 85 percent of the first 5,000 kva plus 95 percent of the remainder of any load over $5,000 \mathrm{kva}$ ) is higher than the $\mathrm{kw}$ demand, such amount will be used as the billing demand. 


\section{PAYMENT}

Above rates and charges are net. In the event that any bill is not paid on or before the delinquent date shown on bill, there shall be added to the bill an amount equal to 10 percent on the first $\$ 250.00$ of the bill plus one percent on any portion of the bill exceeding $\$ 250.00$; to any amount remaining unpaid 30 days after the delinquent date of the bill, there shall be added a penaliy of one percent, and an additional one percent shall be added at the end of each successive 30 day period until the amount is paid in full.

\section{SINGLE POINT DELIVERY}

The above rates and charges are based upon the supply of service through a single delivery and metering point, and at a single voltage. Separate supply for the same customer at other points or at different voltage shall be separately metered and billed.

\section{RULES AND REGULATIONS}

Service under this schedule is subject to the Rules and Regulations of Division. 


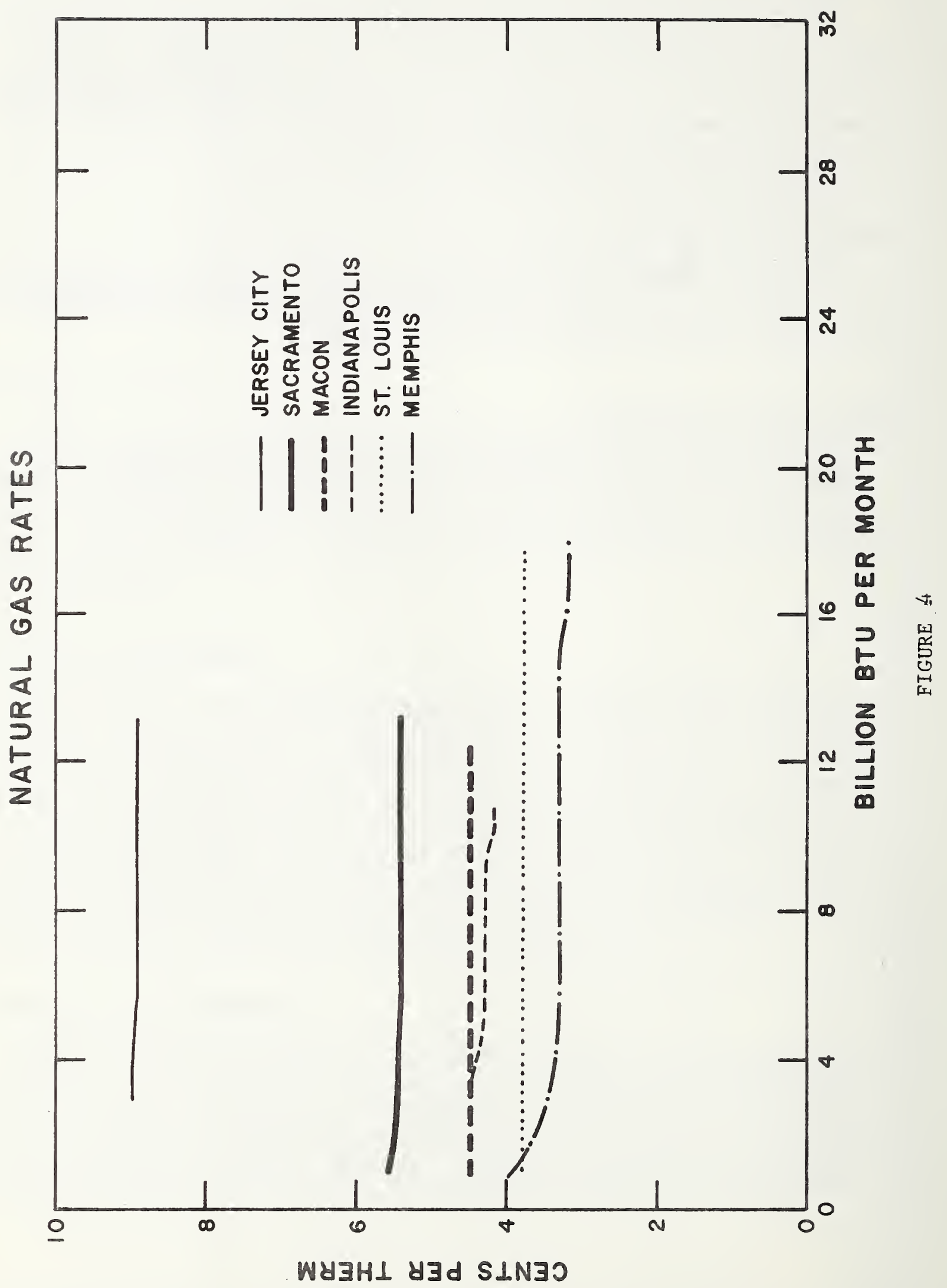




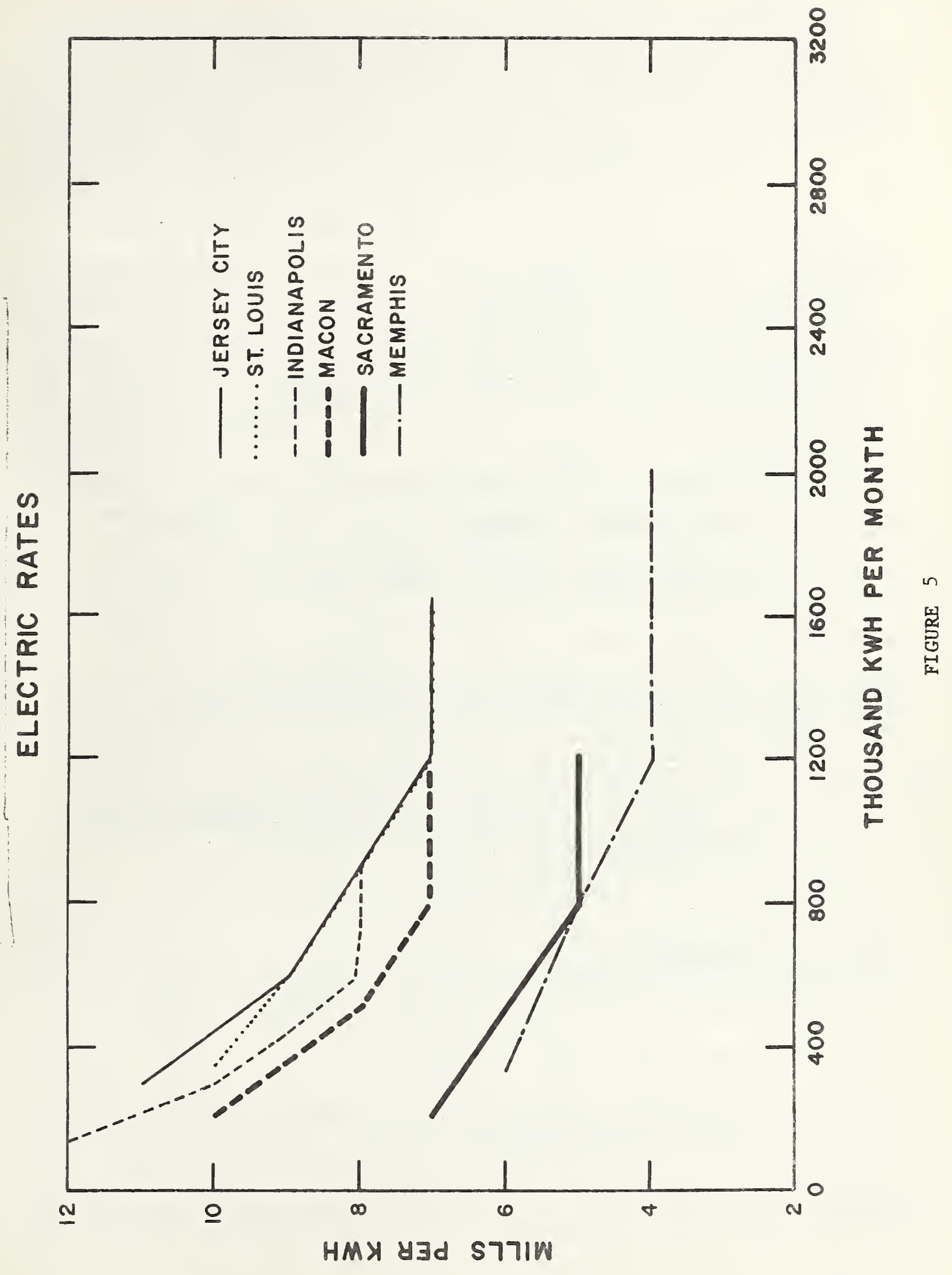


Table 10. Unit Energy Costs ${ }^{1}$

\begin{tabular}{|l|c|c|c|}
\hline \multicolumn{1}{|c|}{ Site } & \multicolumn{2}{|c|}{ Unit Cost } \\
\hline & Oil & Gas & Electricity \\
\cline { 2 - 4 } & Dollars/Gal & Dollars/Btu x 106 & Cents/KWH \\
\cline { 2 - 4 } Jersey City & 0.115 & .890 & $0.700-1.100$ \\
Macon & 0.120 & .450 & $0.700-1.000$ \\
Memphis & 0.119 & .330 & $0.400-0.600$ \\
Indianapolis & 0.110 & .435 & $0.800-1.200$ \\
St. Louis & 0.105 & .380 & $0.700-1.000$ \\
Sacramento & 0.105 & .545 & $0.500-0.700$ \\
\hline
\end{tabular}

${ }^{1}$ Not including any applicable state, local or sales taxes.

${ }^{2}$ Includes energy charge and demand charge.

Table 11. Ratio of Energy Costs per Unit of Heating Value of Fuels

\begin{tabular}{|l|c|c|}
\hline \multicolumn{1}{|c|}{ Site } & Electricity/Gas & Electricity/011 \\
\hline Jersey City & 3.48 & 3.73 \\
Macon & 6.20 & 3.21 \\
Memphis & 6.30 & 2.42 \\
Indianapolis & 7.63 & 4.10 \\
St. Louis & 6.55 & 3.28 \\
Sacramento & 4.56 & 3.30 \\
\hline
\end{tabular}


Comparison of energy costs are given in Table 11, which tabulates the cost ratios of electricity to gas and electricity to oil per unit of heating value of the fuels. This ratio is frequently used as a first approximation in determining whether a total energy system might be economical at a given location. If this ratio is lower than 6 , it will usually be uneconomical for site generation of electric power. However, other parameters such as load factor, density of users, etc., also affect the final decision.

\subsection{First Cost and Operating Cost}

In developing appropriate budget costs for installing either total energy or conventional energy systems at BREAKTHROUGH prototype sites, several cost estimating sources were used. Air conditioning, electrical and heating equipment sizes were determined from the NBS computer load analysis program described in Section 4.3 of this report. The capacity and number of incremental units of each electric generating system were selected so that a minimum of 25 percent excess capacity (for emergencies) was provided.

Sources of cost data in this report are from the following:

1) Building Construction Cost Data 1969, by Robert Snow Means Co., Inc. 27th Edition (usually referred to as "Means").[6]

2) Several energy consultants provided some of the cost information used in this report:

a) H.D.Nottingham and Assoc., Engineers and Architects, Arlington, Va.

b) Ross and Baruzzini, Consulting Engineers, St. Louis, Mo.

c) Truog-Nichols, Consulting Engineers, Kansas City, Mo.

3) Designers, builders, and operators of total energy systems:

a) Ohio Energy Systems, Inc., Columbus, Ohio.

b) Tri-Energy Corporation, Total Energy Systems, Homewood, I11.

4) Equipment suppliers:

a) Caterpillar Tractor Co., Peoria, I11.

b) The Trane Co., La Crosse, Wisc.

c) Noland Company, Falls Church, Va.

Since each of the six sites has a variety of housing types, several different combinations of energy systems are considered in the cost estimates. The estimated costs include construction, overhead, profit, design and cost escalation charges from 1969 to 1970.

Table 12 summarizes all of the plant sizes and system costs.

The Indianapolis, Indiana site is large and features low density distribution of dwelling units. Low density development does not lend itself to total energy application because of long distribution lines for air conditioning (chilled water), heating (steam or hot water) and electrical systems. For conventional systems, extension of utilities to the buildings in a site is provided by the local utility company. When a site uses a 
|

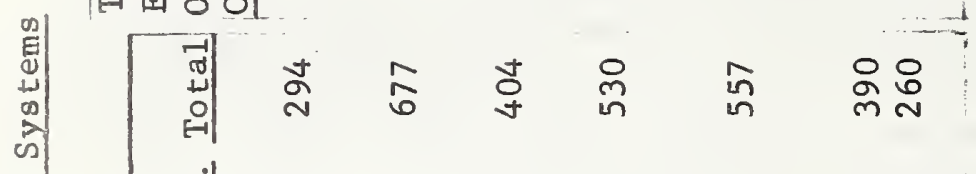

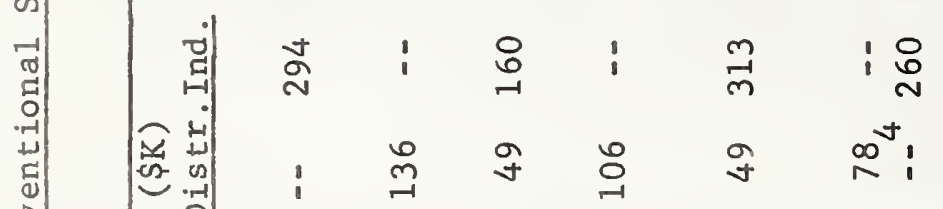

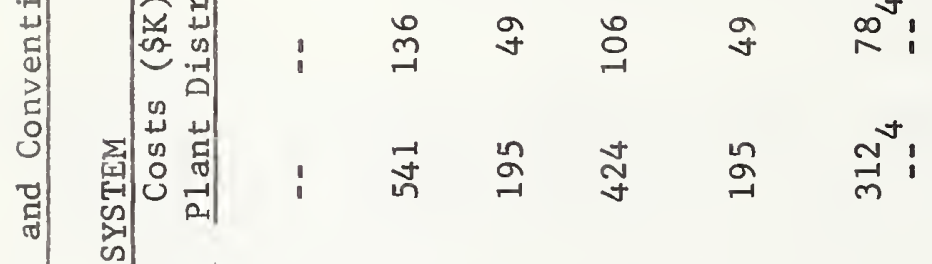

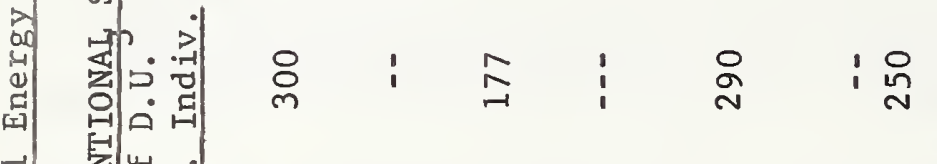

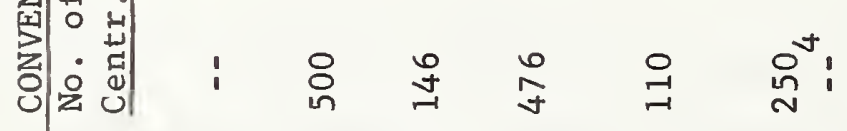

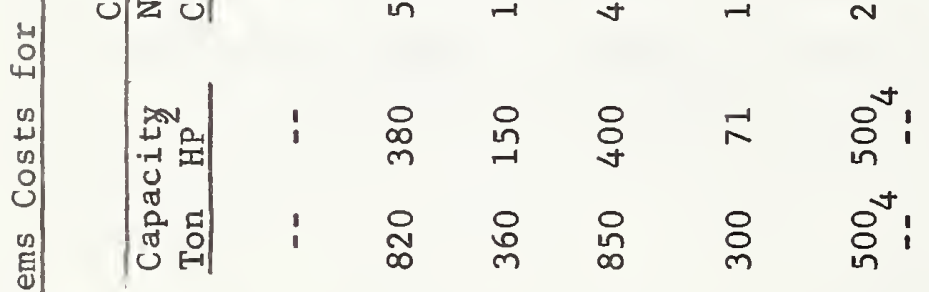

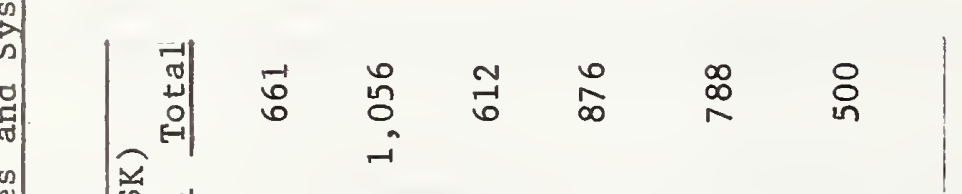

党

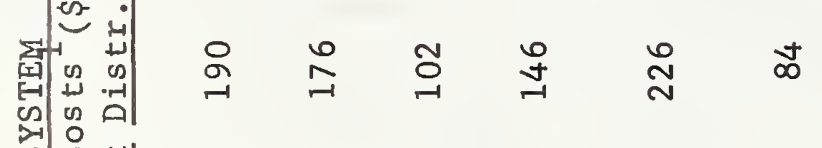

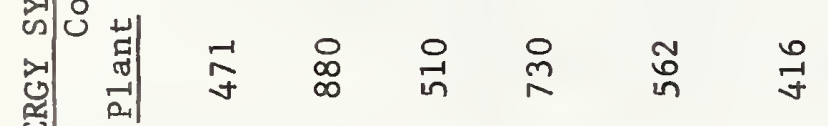

斎

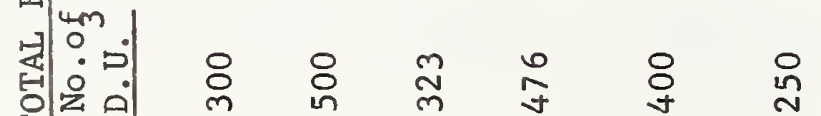

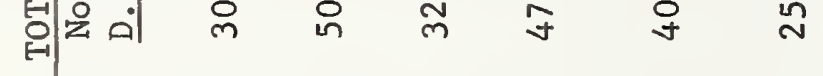

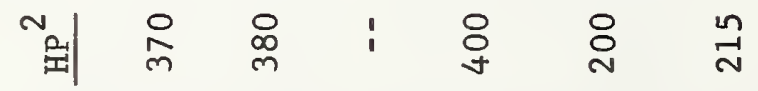

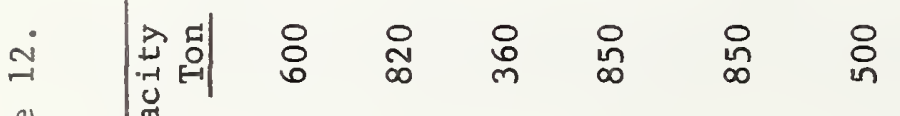

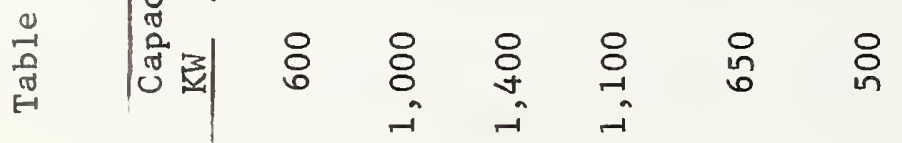

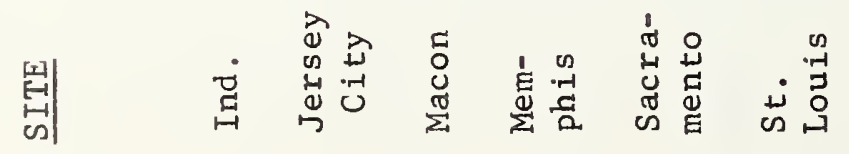

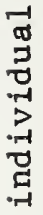

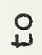

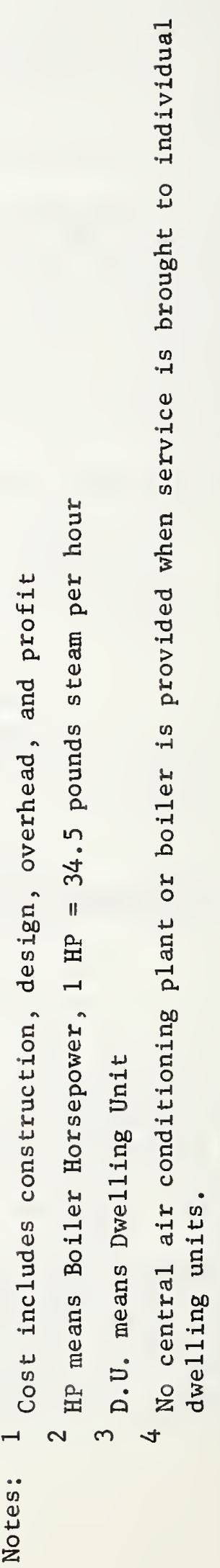


total energy system, all costs of utility extensions, except natural gas or oil, must be added to the cost of the total energy plant.

The total energy system costs: plant -- \$471,000; distribution - $\$ 190,000$ (very high because of the distances involved); total - \$661,000. In the plant are four $150 \mathrm{KW}$ generators, 600 tons of air conditioning machines, and two 185-horsepower boilers.

At Indianapolis the conventional system, which is based upon individual cooling and heating systems at each dwelling unit, will cost \$294,000. Therefore, the extra initial investment for a total energy system at Indianapolis will be $\$ 367,000$. The cost difference for a total energy system at the Indianapolis site would be considerably less, if the comparison were made with a conventional central heating and cooling plant.

Jersey City, New Jersey is a site that adapts very well to central distribution of chilled and hot water and to a total energy system. The total energy system is estimated to cost $\$ 1,056,000$, with $\$ 880,000$ for the plant and $\$ 176,000$ for utility distributions systems. Four $250 \mathrm{KW}$ generators (1000 KW), 820 tons of air conditioning machines (a combination of three or four centrifugal and absorption machines) and two 190-horsepower boilers would be required in the total energy plant.

A conventional system (purchased utilities) at Jersey City will consist of a central cooling and heating plant with chilled and hot water piped to the individual dwelling units. The distribution of fuel and electricity will be partly installed by the local utilities normal extension of services. The central cooling and heating plant will cost $\$ 541,000$ with the distribution system costing $\$ 136,000$ for a total conventional system cost of $\$ 677,000$. The difference between the cost of the total energy system and conventional system is $\$ 379,000$.

Macon, Georgia is proposed for a split total energy system with chilled and hot water and electricity to be generated and distributed to the dwelling units and community building located in the high-rise structure and within a radius of about 500 feet of the high structure. Additional electricity will be generated by the same total energy plant and distributed to the remaining multifamily, townhouse, and single-family dwelling units on the site for all electric service. This represents a unique approach to the problem of total energy application to low density housing complexes. Of the 323 dwelling units on the site, 146 will be provided electricity and chilled and hot water from the total energy plant, and 177 dwelling units will be all-electric.

The total energy plant will have four 350-KW generators for a total of $1400 \mathrm{KW}$, three 120-ton air conditioning machines (360 tons total). The total energy plant cost is $\$ 510,000$, distribution cost $\$ 102,000$, for a total energy system cost of $\$ 612,000$. 
In estimating the cost of a conventional system, a central cooling and heating plant for the high-rise structure and nearby community building and dwelling units is used, and the remaining 177 dwelling units are expected to use conventional individual cooling and heating systems. The central cooling and heating plant cost is $\$ 195,000$, including two 75-horsepower boilers; distribution cost is $\$ 49,000$; and individual units cost $\$ 160,000$ for a total of $\$ 404,000$.

The initial cost difference between the total energy and conventional systems is $\$ 208,000$.

The Memphis, Tennessee site is similar to Jersey City and lends itse1f to either the total energy or central cooling and heating system. Some of the housing units on the east end of the site are not altogether desirable for a central cooling and heating system but for estimating purposes are included. The total energy plant has four 275-KW generators (1100 KW total), a combination of centrifugal and absorption air conditioning machines for a total of 850 tons and two 200-horsepower boilers. The total energy plant costs $\$ 730,000$, distribution $\$ 146,000$ for a total energy system cost of $\$ 876,000$.

The conventional system costs are: central cooling and heating plant $\$ 424,000$; the distribution - $\$ 106,000 ;$ tota1 -- $\$ 530,000$. The initial investment difference between total energy and conventional systems is $\$ 346,000$. Memphis might also be considered for a split system to trade off between more generator capacity and less boiler capacity and distribution costs.

The Sacramento, California site is similar to Indianapolis in that it has a large amount of low density dwelling development. However, it does have a high-rise structure. The total energy plant has four $162.5 \mathrm{KW}$ generators ( $650 \mathrm{KW}$ total), 850 tons of air conditioning, and two 100-horsepower boilers. The total energy system costs are: p1ant - $\$ 562,000$, distribution - $\$ 226,000$; total -- $\$ 788,000$.

The conventional system consists of a central cooling and heating plant for the high-rise structure and individual systems for the remaining dwelling units. Conventional system costs are: plant--\$195,000; distribution - \$49,000; individual units - \$313,000; tota1 -- \$557,000.

The initial cost difference between total energy and conventional systems is $\$ 231,000$.

At St. Louis, Missouri only the east site with 250 dwe 11 ing units is included. The total energy plant has four 125- KW generators (500 KW total), 500 tons of air conditioning, and two boilers totaling 215 horsepower. Total energy system costs are: plant - \$416,000; distribution - \$84,000; total - $\$ 500,000$.

The conventional system can either be a central cooling and heating system or individual cooling and heating plants for each dwelling unit. The central system costs are: plant - $\$ 312,000$; distribution - $\$ 78,000$; total -- $\$ 390.000$. The cost of individual plants for 250 dwe11ing units 
is $\$ 260,000$. Of course, the utility rates for the individual systems are much higher than for the central system.

The initial investment for total energy is $\$ 110,000$ greater than a conventional central plant system, and $\$ 240,000$ greater than the individual system.

Table 13 summarizes the estimated differences in first cost for a total energy installation and a conventional system as developed in Table 12. It also summarizes the annual saving in energy cost (fuel cost) of the total energy system as compared to a conventional system. Two different conventional systems are considered for the Macon, St. Louis, and Sacramento sites: one in which a central plant distributes hot water, chilled water, and domestic hot water to the entire site and electricity is purchased separately from the utility, and the other in which the central plant serves only the high-rise structures and the remainder of the dwellings are served by individual units and electric service, all separately metered.

Finally, the ratio of the annual savings in fuel cost is expressed as a percentage of the increased first cost of the total energy system to indicate a return on investment, if maintenance and operation costs were equal for the two cases. Probably maintenance costs for several hundred individual heating and air conditioning units and water heaters would exceed the cost of maintenance in a total energy plant. However, the maintenance cost for a total energy plant is likely to exceed the maintenance cost for a conventional central plant by a least the cost of minor and major overhaul operations on the gas or diesel engines.

Firms with experience in maintenance and repair of total energy plants for garden apartments indicate that this cost will average about $0.6 \mathrm{c} / \mathrm{KWH}$. On this basis, maintenance and repair costs would range from about $\$ 12,000$ per year for half of the St. Louis site to about $\$ 24,000$ for the Jersey City and Memphis sites. These costs include routine oil changes, minor and major overhauls of the fuel-burning engines, service, adjustment and repair of boilers, chillers and electrical systems. These costs would have to be taken into account in a final appraisal of the economic comparison of a total energy system and a conventional system. 


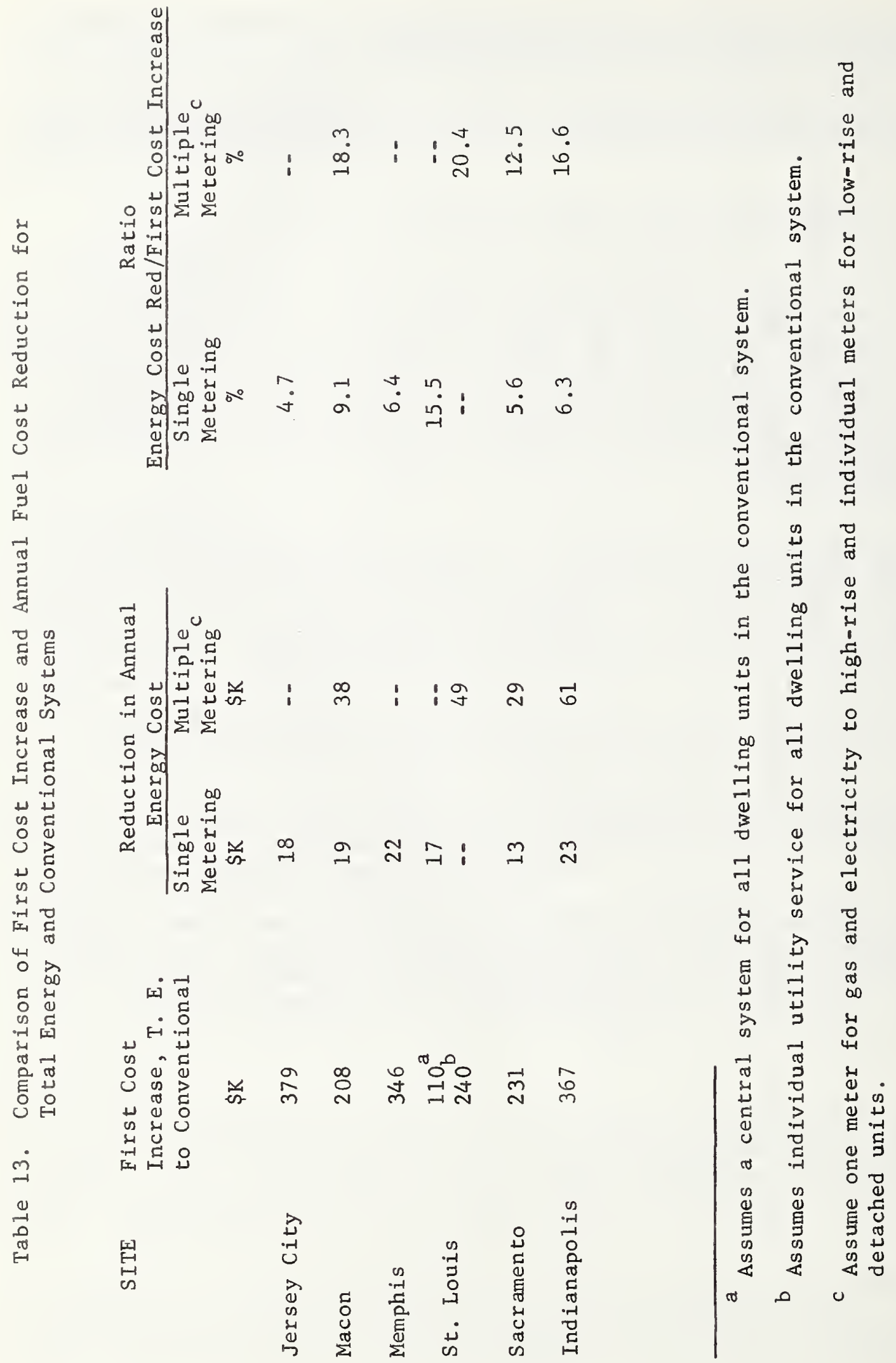




\subsection{Adaptability of Housing Systems to Total Energy}

Twenty-one of the twenty-two housing system producers will be building dwelling units on the six BREAKTHROUGH sites under consideration in this report; namely, Jersey City, Macon, Memphis, St. Louis, Indianapolis, and Sacramento. The number of different systems on one site range from three on the Jersey City site to eight on the Indianapolis and Macon sites.

Constructions that provide cavity walls or sandwich constructions made of wood, foamed insulation, gypsum board and other materials that can be readily cut provide the greatest flexibility in introducing conduits and ducts into the structure. Constructions of masonry and concrete panels that provide for pipe chases at the joints offer an intermediate level of flexibility for conduits for electricity, water and drainage systems. Factory prefabricated volumetric modules must in most cases incorporate a completely preplanned arrangement of service systems, especially if made of masonry.

Every dwelling unit must provide for distribution of electricity, domestic hot and cold water, and an adequate drain, waste, and vent system, whether a total energy system, central or individual heating and cooling system is used for the site. If individual heating and cooling units are used, electricity and gas or oil must be brought to the unit. If a total energy system or a central hot-and-chilled water system provides for space conditioning, either two or four water pipes of relatively small size and electric service must be brought to the central unit in each house. These additional pipes (one to three) can readily be accommodated in cavity walls, pipe chases at panel joints, or in the special utility chases that must be provided in volumetric module housing designs. Thus the adaptation of the total energy concept to the variety of proposed housing systems does not appear to offer any new or major type of design problem.

\subsection{Community Development}

A variety of community and commercial developments is being considered at some of the six sites with which this report is concerned.

The most extensive and most thorough1y developed plans appear to be those for the Jersey City site. These include 12 grade school classrooms of $19,500 \mathrm{sq} \mathrm{ft}$ area, retail stores of $45,000 \mathrm{sq} \mathrm{ft}$ area, a community center of $2,500 \mathrm{sq} f t$ area, a swimming pool of $5,500 \mathrm{sq} f t$ area, and public facilities of 4.000 sa ft area, in addition to considerable covered abovegrade and below-grade parking. These types of facilities will increase the demand for electrical energy and will tend to increase the electric energy requirements proportionately more than the waste heat requirements. This benefits the load factor for a residential total energy system in which the waste heat demands are large relative to the miscellaneous electrical demands. Thus the community development at Jersey City should make that site more attractive as an experiment for a total energy system. 
The developer for the Macon site plans to include a community center and retail stores with an area of $10,000 \mathrm{sq}$ ft in or near the high-rise structure on the site. These loads will provide modest benefits in load factor for this site.

Considerable discussion of the prospects for community development on the Sacramento site was held at the time of the conference with the site planner, site developer, and a county official. The site was also visited, together with the county hospital and other facilities on the old fair grounds. A community center is planned within the boundaries of the BREAKTHROUGH development. Future construction of a medical teaching center for the University of California at Davis, an extension to the county hospital, and commercial development is considered probable. The earliest new construction may begin in about one year.

Several possibilities for joint use of utilities between the BREAKTHROUGH housing site, the county hospital, and the other potential developments on parts of the old fair ground were considered and discussed. These included the following:

1. Buy heated and chilled water services from a power plant expansion of the county hospital, and electric service from the local utility.

2. Expand the hospital plant as a total energy system and obtain all energy services from that source.

3. Promote the construction, under private financing, of a new utility plant midway between the BREAKTHROUGH site and the new medical and hospital facilities to sell services in both directions.

There appeared to be some potential for developing each of these concepts if there were time for completing the arrangements. However, county officials did not appear to have initiated either a financing plan or design activities for new construction. It would take considerable time to develop the plans for the county, university, and commercial facilities to a point where an energy systems firm would be able and willing to build a utility system as an investment to sell services to the BREAKTHROUGH site and to the other facilities to be constructed in the next few years.

The power plant for the existing county hospital is about one-half mile from the nearest part of the BREAKTHROUGH site. It contains some reserve boiler capacity, niainly in boilers about 30 years old, and some standby dieseldriven generator equipment to be used as an emergency power source for the hospital. Conceivably, these facilities could be used to furnish high pressure steam to heat exchange equipment and absorption air conditioning equipment located on the BREAKTHROUGH site, using an underground steam and condensate piping system across the intervening half-mile distance. It is improbable that the hospital administration would be willing to use their emergency diesel generating equipment to furnish electric energy to the BREAKTHI OUGH site on a day-to-day basis. 
Considering the status of the development of these proposed plans for hospital and medical facilities, it was concluded that the time schedule for construction on the Sacramento BREAKTHROUGH site could probably not be met by a cooperative effort on utility systems.

At the Indianapolis site, a community center and some lower-grade classrooms are planned as on-site construction. A school for retarded children is under construction on adjacent ground. However; the energy systems for this facility are already being built. An adult vocational school is planned in an area adjacent to the BREAKTHROUGH site. The community center and grade schools are probably the only non-resident load that would be immediately available to a total energy system at this site, with the vocational school as possible future addition.

Except for a visitors' center, no community facilities were planned for the St. Louis site. No specific community facilities are planned for the Memphis site.

In summary, it was concluded that the Jersey City development had far the best potential for actual construction of community facilities in an amount that would significantly affect the load patterns on a total energy system. If more advance time were available for planning and developing the concept, a major cooperative utility system might be feasible for the Sacramento site. Under the circumstances that exist, it appears unlikely that such a plan could be developed in the time available. Modest community developments will probably be constructed on the Macon and Indianapolis sites.

\subsection{Environmental Factors}

An analysis was made of the effects of a total energy system on the environment of a BREAKTHROUGH site with respect to noise and air pollution, in comparison with other methods of providing these same utility services.

Visits to several installations of total energy systems revealed that noise and vibration control was essential to the acceptability of such a system in a residential community. Potential for excessive noise transmission and vibration from the total energy plant arises from the following sources:

1) Direct transmission of engine room noise through windows and 1 ightweight walls,

2) Direct transmission paths for noise through engine room ventilation intake or exhaust openings,

3) Pulsating exhaust of combustion gases from reciprocating engines,

4) Air and water noise generated in cooling towers, and

5) Transmission of vibrations from reciprocating or rotating machinery to building structures attached to the utility plant. 
Al1 of these features of noise and vibration control require specific attention in the design of the plant, but none presents a problem that cannot be overcome satisfactorily. Existing systems are installed in the basements of occupied apartment buildings or underneath community center facilities without causing objectionable noise and vibration.

Federal, state, and municipal limitations on the amount of particulates and sulfur dioxide that may be discharged into the atmosphere with combustion gases essentially dictate the use of No. 2 fuel oil or its equivalent in residential areas. The problems of fuel storage, ash handling, and particulate and sulfur dioxide discharge make it impractical to use coal in a total energy plant on a BREAKTHROUGH site. Combustion gases from a gas- or oil-burning plant must be discharged at a height that will promote diffusion into the upper atmosphere and they must be discharged at a location that will not allow the prevailiang winds to carry them into nearby dwellings, recreation areas, or other occupied spaces. Likewise, the water vapor emanating from the cooling tower should not create objectionable mist, fog, or frost deposits in occupied areas or traffic areas of the site. These latter problems related to discharge of combustion gases and water vapor dissipation are no different for a total energy plant than for a conventional central heating and air conditioning plant.

\subsection{Energy Resources}

There are dwindling reserves of electric power generating capacity in wide areas of the United States. Especially critical are the eastern seaboard states from New York to Florida and the cities of Chicago, St. Louis, Minneapolis, and St. Pau1. I/ The electrical power shortage emphasizes the relevance of a study of alternative utility options for new housing developments. Concurrently, there are impending shortages of natural gas. In Washington, D. C., and Baltimore no new industrial customer can obtain natural gas service if his requirements exceed $300,000 \mathrm{cu} f t$ per day, and no old customer can increase his requirements by more than $300,000 \mathrm{cu} \mathrm{ft}$ per day. The Boston Gas Co. plans to import gas from Algeria for the coming winter.

The serious state of electric power reserves described above indicates that the application of total energy systems to the BREAKTHROUGH sites in Jersey City, St. Louis, Memphis, and Macon may serve as good and prudent examples of conservation of scarce resources in these particular areas as well as worthwhile experiments for wider consideration. The gas utility serving Jersey $\mathrm{City}$ has not been encouraging the use of gas for a total energy plant at that site. Since fuel oil is a little cheaper than gas in Jersey City at the present time, and because New Jersey is near the end of the gas distribution pipeline from the Texas fields, Jersey City would be a good choice for an experimental oil-burning total energy system.

There appear to be adequate gas reserves at Macon, Memphis, and St. Louis for the BREAKTHROUGH sites. 


\subsection{Site Planners and Site Developer Attitudes toward Use of Total Energy Systems}

The site planner and developer for the Macon site have shown the greatest initiative and interest in the application of a total energy system to the BREAKTHROUGH development. In fact, the planner has proposed that they be authorized to make a feasibility study, produce a design, and carry out field studies of performance after installation.

The site planner for the Jersey City site has expressed a positive attitude about a total energy system there, and is encouraged and supported in this approach by one of the housing system producers.

This producer envisions replacing an initial fuel-burning total energy system in a few years with fuel cells as a direct means for converting chemical energy into electricity. Fuel cells are not sufficiently deve1oped as yet.

The site planner at St. Louis is open-minded about installation of a total energy system provided it does not entail higher capital costs for the developer and does not delay the time schedule. Rouse-Wates, the only housing system producer on the eastern parcel of the St. Louis site, has had a feasibility study of total energy and several other utility systems made to determine economic feasibility. Two firms, submitting feasibility reports, contradict each other; one showing that it will provide a reasonable return on investment and the other showing the opposite conclusion. Rouse-Wates is concerned that the evaluation of their housing system not be burdened with an uneconomical energy system.

The planner and developer for the Memphis site appear to be open-minded about the use of a total energy system, but have taken no initiative in promoting or exploring the concept. The situation at Indianapolis is comparable to that at Memphis.

The site planner for the Sacramento site appeared to favor a cluster utility concept in which the energy would be delivered to a group of dwe11ing units, perhaps 15 or 20, from a facility, centrally located with respect to the group. This would gain the diversity of a small group in selecting equipment capacity without the economic burden of distribution of energy throughout a low-density complex from a central point. The developer appears to be relying on the planner to bring forward a plan and a recommendation.

Few of the site planners seem to give much attention to the experimental aspect of the total energy installation at BREAKTHROUGH I sites. Most are more concerned about economic attractiveness of the proposition and the time schedule.

The importance of gaining reliable information on all aspects of 1 ife cycle costs should be emphasized in this program. In a time of rapidly changing interest rates, equipment costs, energy costs, and labor costs it is difficult to make reliable predictions of the future economic benefits to be derived from a facility of this type. 


\subsection{Time Schedule}

It is important that the design of a total energy plant be completed in time to coordinate the installation with site preparation and the beginning of construction. Since distribution of utilities w111, in most cases, be done underground, the design of total energy system should be completed by the time installation of underground systems begins.

Groundbreaking is scheduled for the Jersey City and Indianapolis sites by the end of September, 1970; for Macon by late October and for St. Louis by late November. Considering the delays in coordinating the efforcs of the various housing system producers, it appears likely that there will be delays in these time schedules. The groundbreaking dates for the Memphis and Sacramento sites appear to be somewhat later.

Five architect-engineer firms with considerable experience in designing total energy systems were asked for estimates of the time required to complete a system design. The estimates ranged from six weeks to twelve weeks.

In view of the probable time schedules cited above for groundbreaking, it is imperative that contracts for design be expedited.

\subsection{Application of Ranking Parameters to Six Sites}

A comparison was made of the six sites at Jersey City, St. Louis, Indianapolis, Memphis, Sacramento, and Macon, one with another, by assigning a ranking of 1 to 6 for each of the parameters discussed in Sections 3 and 4 of this report. A ranking of 1 indicates highest suitability and 6 , the lowest suitability for that particular parameter. In a few cases, however, two sites were ranked equally when a basis for differentiating between them did not appear to exist. Table 14 summarizes the results of this ranking process.

There is considerable subjective judgment involved in considering some of the parameters, since numerical scales are not involved. Some of the parameters are regarded more significant than others. In particular, the density and arrangement of the dwelling units on the site are the more important site factors; the ratio of the annual reduction in fuel cost to the difference in first cost between a total energy system and a conventional system is the most important economic factor; and the attitude of the site planner and developer and the compatibility of the total energy system development to the construction time schedule are the more important administrative parameters.

Either an equal weighting of all parameters or the use of the five more significant ones identified above indicates that Indianapolis is the least suited to a total energy system. 
Table 14. Rank Ordering of Six BREAKTHROUGH I Sites

for Experimental T. E. Systems

\begin{tabular}{|c|c|c|c|c|c|c|}
\hline Ranking Parameters & $\begin{array}{l}\text { Jersey } \\
\text { City } \\
\end{array}$ & $\begin{array}{l}\text { St. } \\
\text { Louis }\end{array}$ & $\begin{array}{l}\text { Indiana- } \\
\text { polis }\end{array}$ & Memphis & $\begin{array}{l}\text { acra- } \\
\text { mento }\end{array}$ & Macon \\
\hline No. of D.U.'s & 1 & 3 & 6 & 2 & 4 & 5 \\
\hline Density of D.U.'s & 1 & 2 & 5 & 3 & 4 & 6 \\
\hline Arrangement on site & 2 & 3 & 6 & 1 & 4 & 5 \\
\hline Winter Degree Days & 5 & 4 & 6 & 3 & 1 & 2 \\
\hline Summer Degree Days & 5 & 4 & 6 & 2 & 3 & 1 \\
\hline Winter Design Temp. & 4 & 5 & 6 & 3 & 1 & 2 \\
\hline Cost Ratio, Elec to Gas & s 6 & 2 & 1 & 3 & 5 & 4 \\
\hline Cost Ratio, Elec to Oil & 12 & 4 & 1 & 6 & 3 & 5 \\
\hline $\begin{array}{r}\text { Cost Diff., T.E. to } \\
\text { Convent. }\end{array}$ & 6 & 3 & 4 & 5 & 2 & 1 \\
\hline $\begin{array}{l}\text { Benefit of Comm. Dev. } \\
\text { to Load Factor }\end{array}$ & 1 & 5 & 3 & 6 & 4 & 2 \\
\hline $\begin{array}{l}\text { No. of Diff. Housing } \\
\text { Systems }\end{array}$ & 2 & 1 & 5 & 3 & 4 & 5 \\
\hline $\begin{array}{l}\text { Adaptability of Hous- } \\
\text { ing Systems }\end{array}$ & 4 & 4 & 3 & 5 & 2 & 1 \\
\hline Elec. Reserve at Site & 1 & 2 & 4 & 2 & 5 & 3 \\
\hline $\begin{array}{l}\text { Attitude of Site Plan- } \\
\text { ner, Site Developer }\end{array}$ & 2 & 4 & 6 & 3 & 5 & 1 \\
\hline $\begin{array}{l}\text { Compatibility with Time } \\
\text { Schedule }\end{array}$ & 6 & 3 & 5 & 2 & 1 & 4 \\
\hline \multicolumn{7}{|l|}{$\begin{array}{l}\text { Ratio of Annual Savings } \\
\text { on Energy Cost to Diff. } \\
\text { in First Cost between } \\
\text { T. E. and Conventional }\end{array}$} \\
\hline
\end{tabular}


When the five more important ranking parameters selected above are used by themselves, the order of priority is Memphis and St. Louis, tied for first priority; then Jersey City, Sacramento, Macon, and Indianapolis, in that order. When all of the ranking parameters in Table 14 are given equal welght, the order of prlorlty is Macon, St. Jouls, Sacramento; Jersey City, and Memphis, tied for fourth place; and Indianapolis. 
Consideration was given to the integration of a total energy system and a solid waste disposal system on the BREAKTHROUGH sites. Conceivably, there could be the following interfaces between the two systems:

a) Common use of plant space for major equipment components,

b) Use of electric energy from the total energy plant for prime movers in the solid waste disposal system,

c) Combustion of the solid waste in an incinerator adapted to the generation of waste heat in the form of steam or hot water for the total energy system.

The location of the major equipment components for a central solid waste collection system, such as the vacuum system, in the same structure provided for the total energy system, appears logical and feasible. Both systems are more efficient if the length of distribution or collection lines are of minimum length. Thus the best location for each would often be in the same area. Attention must be given to noise control and to proper techniques for exhausting combustion gases or other contaminated air in both systems. Therefore, it is probable that economies in noise attenuation and air pollution control might be effected by adjacent location in common building areas of the equipment for the two systems.

Since central solid waste systems would normally be operated on an intermittent basis, it is probable that the daily or twice-a-day operation of the major energy-using components of this system could be scheduled during periods of light load on the electric generator, thus building up the load factor without requiring an increase in the generator capacity.

Reclamation of the waste heat produced by the combustion of solid waste in the form of steam or hot water seems impractical at this time on the BREAKTHROUGH sites. There are no incinerators of appropriate size fitted with water jackets or water tubes for heat recovery available in the United States, according to information received from the Bureau of Solid Waste Management of the U.S. Public Health Service. There are installations of water-jacketed incinerators in the United States, but they are of much larger capacity than would be required on any of the BREAKTHROUGH sites.

About a half-dozen companies manufacture equipment for incineration of domestic solid waste which can meet most state and municipal requirements with regard to particulates and condensibles in the effluent gases. Some of these systems have been tested and approved by the Air Pollution Control Administration. These incinerators operate on a batch basis and must be shut down at intervals for removal of the solid residue. A typical system can handle $2,000 \mathrm{lb} / \mathrm{hr}$ of solid waste and would use $6,000 \mathrm{cu} \mathrm{ft}$ per hour of gas in an afterburner section to assure complete combustion. However, incinerators of this type and size have not been built with water jackets or water tubes for waste heat recovery as yet.

Such a development might be available in some future cycle of BREAKTHROUGH operations. 


\section{RECOMMENDATIONS}

It is recommended that a total energy system be installed at either the Jersey City or Memphis site even though the calculated return in reduced energy costs is only about 7 percent of the additional first cost entailed by a total energy system. The methods for cost estimation and the precision in calculating loads are not good enough to know whether this ratio is below 5 or above 10 percent. It is highly probable that the occupants would receive their utility services at a cost no greater than from a conventional system and have the benefit of greater reliability and be free of the sources of noise at each dwelling unit caused by individual air conditioning. There would also be an overall saving in energy consumption.

If the installation did not show a sufficient overall saving to represent a good return on the greater first cost, as a result of the field study, this would represent the findings of this experiment for the guidance of HUD in future applications of total energy systems to mixed housing developments.

Jersey City is recommended as the first choice of the two sites because it has the most extensive community development and because of the greater interest on the part of the site planner. If the time schedule makes an installation impractical at Jersey City, Memphis should be used as a second option. Memphis has the highest percentage of high-rise dwelling units and is otherwise well-arranged for a total energy system. The relative cost of purchased electricity and gas favors Memphis over Jersey City.

The site at Macon is recommended as the second choice for installation of a total energy system because it offers a good opportunity for an experiment with a split system in which the more densely occupied portion of the site is supplied heated and chilled water from a central total energy system, and the more remote dwelling units are operated as all-electric units with the electric energy being supplied from the total energy plant. Such a split system is unique for apartment developments as far as can be determined. The cost analysis indicates that the reduction in annual energy cost would be 9 percent of the difference in first cost between the total energy system and a conventional system using single metering, and up to 18 percent if the utilities are individually metered to about half of the units. The site planner and site developer are very much interested in this concept and are eager to participate in the design and evaluation of the system. The split system offers the possibility of eliminating a supplementary steam boiler by proper proportioning of the all-electric units to those receiving chilled and heated water.

The eastern half of the St. Lo uis site is recommended as the third choice for installation of a total energy system for comparison with a conventional system on the western segment. Since the two halves of the site are equal in size and have a similar development pattern, it offers an unusually 
good opportunity for comparison. Calculations indicate that the reduction in fuel cost occasioned by a total energy system on the east site would be about 14 percent of the increased first cost of the total energy system when compared to a central conventional system with single metering of the utilities. If utilities are brought to all dwelling units and individually metered the reduction in energy cost w11 be even greater: approximately 18 percent.

\subsection{Summary of Recommended Insta1lations}

\section{First Cholce -- Jersey City}

Install multiple diesel-burning engines to drive electric generators since fuel oil is a little cheaper than gas in Jersey City and availability is equal or better than gas. Use a combination of reciprocating engine-driven and absorption water chillers for air conditioning to reduce total energy use.

Alternate first choice -- Memphis

Install multiple natural gas engines to drive electric generators. Use a combination of reciprocating engine-driven and absorption water chillers for air conditioning to reduce total energy use in sunmer. Explore application of split system using some al1-electric units to eliminate or minimize supplementary heat requirement and to reduce distribution cost.

\section{Second choice -- Macon}

Install a split total energy system. Divide housing area between all-electric units and those served by hot and chilled water to reduce distribution costs and to eliminate need for supplementary boiler, winter or summer. Use a central domestic hot water heating tank as a heat sink for surplus waste heat and use electric water heating in remote units to obtain balance between electric load and waste heat requirements.

\section{Third choice -- St. Louis}

Install multiple natural gas engines to drive electric generators on east site. Use a combination of reciprocating engine-driven and absorption water chillers for air conditioning to reduce total energy use in summer. Observe performance, reliability, maintenance, and customer satisfaction on both east and west sites for comparison of total energy and conventional systems. 
1. Lucien, J. Lucke11, GATE Reports: Study Report of Economic Feasibility of a Total Energy Plant at Amalgamated Warbasse Houses, Brooklyn, New York (1967).

2. Lucien, J. Lucke11, GATE Reports: Analysis of One Year's Operation of the Total Energy Plant at Amalgamated Warbasse Houses, Brooklyn, New York (1967).

3. Lucien, J. Luckell: Similar reports as 1 and 2 for Rochdale Village, Jamaica, Long Island, New York (1967).

4. P. R. Achenbach, et al, Analysis of Electric Energy Usage in Air Force Houses Equipped with Air-toAir Heat Pumps, NBS Monograph 51, 1962.

5. Edison Electric Institute, Wattage Rating and Estimated Average Annual KWH Consumption of Electrical Household Appliances Assuming Normal Use, (Jan. 1961).

6. Building Construction Cost Data 1969, Robert Snow Means Co., Inc. 27th Edition.

7. Newsweek, May 18, 1970, "Warning: Low Voltage," page 123. 

